\title{
Kotorski plemić i zapovjednik mletačkih prekomorskih pješaka Stjepan Buća i sastav njegove pukovnije (prva polovica 18. stoljeća) $)^{* * *}$
}

Ovaj rad proučava vojnu karijeru Stjepana Buće, kotorskoga plemića i časnika mletačke vojske u 18. stoljeću. Pripadnici ove ugledne kotorske plemićke obitelji generacijama su se isticali u obnašanju važnih službi Mletačke Republike. Posljednjih desetljeća 17. stoljeća, u vrijeme ratova protiv Osmanlija, Buće ulaze u vojnu službu Republike. Upravo Stjepan, njegov brat Franjo i njihov otac Jeronim ostvaruju vrlo zapaženu vojnu karijeru. Stoga se proučavanjem vojne karijere ovih časnika, a rad je usredotočen na Stjepanovu, jasno ocrtava obrazac integracije lokalnih elita istočnojadranskoga prostora u mletački pomorski imperij. Sadržaj rada počiva na proučavanju izvorne građe nastale djelovanjem mletačke vojne administracije, koja se danas nalazi pohranjena u Archivio di Stato di Venezia i Državnome arhivu u Zadru. Glavni dio rada usmjeren je na analizu pješačke pukovnije Oltramarina u razdoblju od 1715. do 1741. godine, kojom je zapovijedao pukovnik Stjepan Buća. U prilogu rada donose se prijepisi dokumenata izravno vezanih uz vojno djelovanje Stjepana Buće kao pukovnika mletačkih pješačkih postrojbi.

Ključne riječi: Kotor, Boka kotorska, Stjepan Buća, Mletačka Republika, mletačka vojna organizacija, rani novi vijek.

\section{Uvod}

Jedan od ključnih uvjeta izgradnje i održavanja mletačkoga pomorskog imperija u ranome novom vijeku bilo je uspješno povezivanje interesa lokalnih elita i središnje vlasti. ${ }^{1}$ Iznimka, dakako, nisu bili ni mletački istočnojadranski posjedi,

\footnotetext{
* Lovorka Čoralić, Hrvatski institut za povijest, Opatička 10, 10000 Zagreb, Republika Hrvatska, Email adresa: lovorka@isp.hr

** Nikola Markulin, Nikole Tesle 14D, 23000 Zadar, Republika Hrvatska, E-mail adresa: nikola.markulin@gmail.com

**** Ovaj rad sufinancirala je Hrvatska zaklada za znanost projektom broj 3675.

1 O važnosti povezivanja interesa lokalnih elita i države za izgradnju mletačkoga pomorskog imperija vidi: Monique O' Connell, Men of Empire: Power and Negotiation in Venice's Maritime State (Baltimore:
} 
a osobitu su važnost u ovim odnosima imale plemićke obitelji dalmatinskih i bokeljskih komuna. Generacije su njihovih pripadnika diljem spomenutih prostora obnašale različite državne službe lokalnoga značenja. Od sredine 17. stoljeća, nakon što su poslije više od sedam desetljeća mira obnovljeni veliki mletačkoosmanski sukobi, a spomenuti prostori postali strateško bojište, sve su se češće lokalne elite angažirale u mletačkim vojnim službama. Na taj je način mletačka vojna organizacija na istočnojadranskome prostoru postala najvažnije polje na kojemu su se ispreplitali i čvrsto povezivali interesi središnje vlasti u Veneciji i lokalnih elita. I dok je to za organizaciju mletačke teritorijalne milicije (u domaćoj historiografiji poznatije pod nazivima cernide i krajine), koja je bez lokalnoga znanja praktički bila neostvariva, bilo logično očekivati, gotovo eksponencijalni rast profesionalnih mletačkih vojnih postrojbi podizanih na širemu istočnojadranskom prostoru na neki je način iznenađujući. On bi bio nezamisliv bez velikoga angažmana lokalnih elita. Budući da administrativni aparat Mletačke Republike, slično kao i svih suvremenih europskih država, nije imao kapacitete sam organizirati vlastite profesionalne postrojbe, država se nužno oslanjala na privatnu inicijativu vojnih poduzetnika. Upravo se tu otvarao prostor angažmanu lokalnih elita, koje su na istočnojadranskome prostoru novačile, ustrojavale i uzdržavale profesionalne postrojbe za koje su se u spisima vojne administracije s vremenom ustalili nazivi Oltramarini (pješaštvo) i Croati a Cavallo (konjaništvo). Zapovjedništvo (i vlasništvo) nad postrojbama (osobito onima većim odnosno pukovnijama) često se unutar jedne obitelji prenosilo s generacije na generaciju, a neki su se od njihovih pripadnika uspjeli u svojoj karijeri uspeti do najviših generalskih činova mletačke vojske. ${ }^{2}$

Izvrstan primjer za proučavanje ovakvoga obrasca integracije lokalnih elita i države pružaju plemići Buća (Bucchia) iz Kotora, koji su se ubrajali među drevne i osobito ugledne kotorske plemićke obitelji. Neki su se pripadnici obitelji u ranome novom vijeku istaknuli kao diplomati, crkveni dostojanstvenici i umjetnici (ponajprije pisci i kroničari), a njihove su karijere već bile predmet interesa domaće historiografije. ${ }^{3} \mathrm{U}$ ovome radu proučit ćemo karijeru nekolicine pripadnika obitelji koji su u posljednjim desetljećima 17. i u prvoj polovici 18. stoljeća

The Johns Hopkins University Press, 2009). Općenito, na teorijskoj razini o takvim procesima vidi: Wolfgang Reinhard, ur., Power Elites and State Building (New York: Oxford University Press, 2005).

2 O ovome fenomenu i vojnoj organizaciji u Dalmaciji i Boki u 17. i 18. stoljeću podrobnije vidi u: Nikola Markulin, "Vojno poduzetništvo u Mletačkoj Dalmaciji i Boki za vrijeme Morejskog rata (1684. 1699.)", Radovi Zavoda za povijesne znanosti HAZU u Zadru 56 (2014): 91-142; Nikola Markulin, "Mletačka vojna organizacija u Dalmaciji i Boki od Morejskog rata (1684. - 1699.) do Požarevačkog mira 1718." (doktorska disertacija, Sveučilište u Zadru, Zadar, 2015); Nikola Markulin, "Vojno poduzetništvo u Mletačkoj Dalmaciji i Boki od 1700. do 1718. godine”, Povijesni prilozi 35 (2016), br. 51: 159-196.

3 Općenito o obitelji Buća vidi u: Stjepan Krasić, Tatjana Radauš, "Buća, plemićka obitelj u Kotoru”, u: Hrvatski biografski leksikon, sv. 2 (Zagreb: Jugoslavenski leksikografski zavod "Miroslav Krleža", 1989), 410-412. O obitelji Buća u 18. stoljeću vidi u Maja Katušić, "Društvena i demografska struktura Kotora u 18. stoljeću” (doktorska disertacija, Sveučilište u Zagrebu, Hrvatski studiji, Zagreb, 2013), passim. 
služili u profesionalnim postrojbama mletačke vojske dosegnuvši pritom visoke vojne činove, a središnja je, pak, tema ovoga istraživanja vojna služba Stjepana (Steffano) Buće i podrobna analiza postrojbi kojima je u 18. stoljeću zapovijedao. Valja ovdje dodati kako su, pored obitelji Buća, važnu ulogu u mletačkoj vojsci 17. i 18. stoljeća s visokim časničkim činovima (bojnici, pukovnici, brigadiri i generali) pješačkih i konjaničkih postrojbi imali i drugi Bokelji - pripadnici plemićkih obitelji. O nekima od njih (iz obitelji Buća, Gregorina, Paskvali/Pasquali, Štukanović/Stucanovich, Visković/Viskovich, Vraćen/Vrachien i drugi) napisano je proteklih godina više znanstvenih radova objavljenih u domaćim i inozemnim znanstvenim časopisima. ${ }^{4}$

Istraživanje se temelji na proučavanju izvorne građe iz Archivio di Stato di Venezia, ponajprije spisa magistrature Inquisitori sopra l'amministrazione dei pubblici ruoli zadužene za postupak novačenja pješačkih i konjaničkih postrojbi na području Veneta i duž istočnojadranske obale te spisa mletačke vojne administracije pohranjenih u Državnome arhivu u Zadru (Generalni providuri za Dalmaciju i Albaniju). Osim rekonstrukcije vojne karijere Stjepana Buće, pri čemu je bilo neizbježno osvrnuti se na vojnu službu koje su obnašali njegovi najbliži srodnici (poglavito otac i brat), središnji dio rada čini raščlamba spisa iz spomenutoga fonda mletačke magistrature za novačenje na osnovi kojih se bavimo Bućinim djelovanjem u činu pukovnika mletačkih prekomorskih pješaka (Oltramarini) tijekom više desetljeća 18. stoljeća. Uz navođenje satnija unutar Bućine pukovnije, kao i njihovih zapovjednika, posebna se pozornost pridaje pukovnikovim osobnim satnijama (compagnia propria) te se podrobno raščlanjuje zavičajno podrijetlo, ali i neke (tjelesne) osobine časnika, dočasnika i običnih vojnika koji se u ovome izvoru spominju.

\section{Plemićka obitelj Buća u vojnoj službi Mletačke Republike uz osvrt na vojnu karijeru Stjepana Buće}

Sudeći po spisima mletačke vojne administracije, pripadnici obitelji Buća u vojnu su se službu Mletačke Republike uključili relativno kasno. Naime, većina visokih mletačkih časnika s konca 17. i u 18. stoljeću podrijetlom s istočnojadranskoga prostora pripadala je obiteljima čiji su pripadnici generacijama, nerijetko od 16. stoljeća, služili u mletačkoj vojsci, odnosno tek u vrijeme Morejskoga rata (1684. - 1699.) kada se spominju Jeronim i Franjo Buća. ${ }^{5}$ Franji, koji se stavlja na

\footnotetext{
${ }_{4}$ Podrobnije o udjelu Hrvata, ali i pripadnika drugih naroda sa širega područja istočnoga Jadrana u mletačkim prekojadranskim postrojbama vidi u bilješci br. 4 u radu: Lovorka Čoralić, "Albanski vojnici u mletačkim prekojadranskim kopnenim postrojbama (18. stoljeće)", Povijesni prilozi 37 (2018), br. 54: 185-186. U istoj se bilješci mogu pronaći i druge brojne bibliografske jedinice koje se odnose na ulogu visokih časnika iz Boke kotorske u mletačkim prekomorskim kopnenim postrojbama.

5 Tridesetih godina 17. stoljeća u državnoj se službi spominju Tripun i Jeronim Buća, prvi kao pomoćnik u ajništvu generalnih providura (Coadiutore della Secretaria), a drugi kao upravitelj državnih skla-
} 
raspolaganje državnim vlastima, generalni providur Pietro Valier 1685. godine dodjeljuje plaću od pet dukata mjesečno bez obzira na angažman, a 1706. godine nalazimo ga u službi guvernadura (Governatore) Risna s plaćom od dvadeset dukata i dodatkom od dvije lanze spezzate na mjesec. ${ }^{6}$

Jeronim Buća priključio se mletačkoj vojsci, kako navode službeni spisi, početkom Morejskoga rata. Spominje se kako je njegov otac imao velike zasluge u upravljanju pograničnim područjem prema Osmanskome Carstvu i kako je Jeronim vojnu službu započeo u mladenačkoj dobi (età più tenera) kada je bio postavljen za časnika u jednoj satniji talijanskoga pješaštva (Fanti Italiani). ${ }^{7}$ Devedesetih godina Jeronim je zapovjednik (i vlasnik) konjaničke satnije Croati a cavallo $\mathrm{s}$ činom kapetana, a uz tu funkciju generalni providur Daniel Dolfin postavio ga je 1693. godine za guvernadura Grahova (u današnjoj Crnoj Gori) istaknuvši kako će imati vrhovno zapovjedništvo nad teritorijalnom milicijom i profesionalnim vojnicima koji budu na tim položajima te kako će ujedno imati i zapovjedništvo nad ljudima iz Risana. Valja spomenuti kako se u jednome spisu s početka 18. stoljeća navodi da je Jeronim Buća - prije nego li je postao guvernadur Grahova, a vrlo izgledno i prije nego li je započeo profesionalnu vojnu karijeru - bio kapetan Contada grada Kotora, odnosno kako je obnašao važnu funkciju u sklopu mletačke teritorijalne vojne organizacije. ${ }^{8}$ Plaću kapetana lakoga konjaništva (25 dukata na mjesec) trebao je, nakon izbora za guvernadura Grahova, zadržati, ali je zapovijedanje nad svojom postrojbom trebao povjeriti jednom guvernaduru kojega će sam izabrati. ${ }^{9}$

Neposredno nakon rata, 1701. godine kapetan Jeronim Buća za svoju je vjernost i hrabrost (navodi se kako je u ratu bio ranjen) nagrađen ugovorom (Condotta) o vojnoj službi u trajanju od sedam godina (pet godina di fermo i dvije dodatne godine di rispetto) za što je trebao primati godišnju plaću u iznosu od četiristo dukata. Ujedno je trebao nastaviti zapovijedati i upravljati vlastitom konjaničkom satnijom. ${ }^{10}$ Iduće je godine sklopio ugovor o novačenju konjaničke satnije (Capelletti a Cavallo di natione Oltramarina, Crovata et Albanese) u sklopu pukovnije pukovnika Karla Benje (Begna) te je, nakon što je dovršio ustrojavanje

dišta u Kotoru i tamošnjega fontika (Sopra mastro alle monitioni et fontico). No, iz dostupnih izvora nije moguće utvrditi jesu li (i ako jesu) u kakvoj rodbinskoj vezi bili s časnikom Jeronimom Bućom koncem 17. stoljeća. Vidi: Hrvatska (dalje: HR) - Državni arhiv u Zadru (dalje: DAZD) - fond 1 - Generalni providuri za Dalmaciju i Albaniju (dalje: GPDA), kut. 6, str. 224, 249; kut. 7, str. 6; kut. 8, str. 287.

6 HR-DAZD-1-GPDA-kut. 53, str. 151; kut. 70, str. 45v. O dodatku na plaće vojnih dužnosnika izraženome u obliku lanza spezzata vidi u: Markulin, "Mletačka vojna organizacija": 81. Podobnije o Bućama djelatnim u mletačkoj vojsci vidi: Lovorka Čoralić, Maja Katušić, "Kotorski plemići Frano Buća, Gabrijel Vraćen i Nikola Paskvali - časnici mletačkih prekojadranskih vojnih postrojbi (prva polovica XVIII. st.)", Povijesni prilozi 31 (2012), br. 42: 250-256.

7 HR-DAZD-1-GPDA-kut. 64, str. 577-578.

8 HR-DAZD-1-GPDA-kut. 65, str. 60-61.

9 HR-DAZD-1-GPDA-kut. 60, str. 130, 409-409v; kut. 65, str. 281v.

${ }^{10}$ HR-DAZD-1-GPDA-kut. 65, str. 60-61. 
postrojbe, za njezinoga zapovjednika postavio, kako se u spisu navodi, Franju, jednoga od svojih maloljetnih sinova. ${ }^{11}$ Uobičajena klauzula ugovora podrazumijevala je da će Jeronim o vlastitome trošku uzdržavati jednoga guvernadura, koji će zapovijedati postrojbom dok Franjo ne postane punoljetan - praksa je iz koje se jasno zrcali velik udio privatne inicijative u organizaciji profesionalnih postrojbi. ${ }^{12}$ Nekoliko mjeseci poslije toga u jednome se spisu navodi kako je Jeronim Buća dopukovnik (Tenente colonnello). ${ }^{13}$ Godine 1709 . istekao je njegov ugovor pa je nagrađen novim u istome trajanju (pet i dvije dodatne godine) uz povećanje godišnje plaće na petsto dukata. Tom prilikom navodi se kako je u vojnoj službi prošao sve vojne činove i kako trenutno ima čin pukovnika (nije jasno radi li se o pukovničkome činu profesionalne vojske ili pukovniku teritorijalne vojne organizacije).${ }^{14} \mathrm{U}$ međuvremenu je satnija njegovoga sina Franje bila uvrštena u konjaničku pukovniju pukovnika Nikole Divnića/Difnico. ${ }^{15}$ Izbijanje novog rata 1714. godine između Mletačke Republike i Osmanskoga Carstva pružilo je Jeronimu Bući nove mogućnosti širenja utjecaja u vojnoj službi.

Otprilike tijekom prve godine rata Jeronim Buća (sada naveden kao nadintendant - Sopraintendente) s državom je sklopio ugovor o novačenju čitave pješačke pukovnije Oltramarina (od nominalno petsto vojnika raspoređenih u deset satnija) kojoj će za pukovnika postaviti sina Stjepana. Početkom 1716. godine generalni providur je - uvidjevši kako su ispunjeni uvjeti ugovora i kako je kompletirano čitavih sedam satnija te kako su još dvije popunjene ljudstvom do pola, odnosno da je unovačeno više od dvije trećine ljudstva čitave pukovnije - Stjepana Buću postavio za pukovnika Oltramarina (pukovnička plaća u to je vrijeme iznosila četrdeset dukata na mjesec). ${ }^{16}$ Ubrzo je slijedilo imenovanje ostatka časničkoga kadra pukovnije. Taj se posao u ovome razdoblju najčešće obavljao na takav način da je nositelj ugovora o novačenju imenovao sve časnike koje su generalni providur, a potom i središnja vlast, samo potvrđivali. Nerijetko se, a u ovome je slučaju tomu bilo tako, radilo o ljudima koji su bili podizvođači ugovora i koji su se (formalno ili neformalno) s nositeljem ugovora dogovorili o novačenju jedne ili nekoliko satnija kojima bi ih on potom postavio za zapovjednike. ${ }^{17} \mathrm{U}$ veljači je Jakov Paskvali, inače veteran i kapetan Contada, unovačivši jednu satniju za Bućinu pukovniju, postao njezin bojnik, a potom su uslijedila imenovanja Jova Đurđevića, Marka Raffaelija, Iva Maine (Krapović), Petra Radova, Ivana Kostića

\footnotetext{
${ }^{11}$ HR-DAZD-1-GPDA-kut. 64, str. 577-578.

${ }^{12}$ Opširno o tome: Markulin, "Mletačka vojna organizacija"; Markulin, "Vojno poduzetništvo u Mletačkoj Dalmaciji i Boki od 1700. do 1718. godine."

${ }^{13}$ HR-DAZD-1-GPDA-kut. 65, str. 73v.

${ }^{14}$ HR-DAZD-1-GPDA-kut. 73, str. 85-86v.

${ }^{15}$ HR-DAZD-1-GPDA-kut. 70, str. 181-182.

${ }^{16}$ HR-DAZD-1-GPDA-kut. 81, str. 225-226, 267-268.

${ }^{17}$ Opsežnije vidi u: Markulin, "Mletačka vojna organizacija"; Markulin, "Vojno poduzetništvo u Mletačkoj Dalmaciji i Boki od 1700. do 1718. godine."
} 
i Filipa Lulića za zapovjednike satnija odnosno kapetane (svaki je pritom unovačio jednu satniju). Za još jednog kapetana je ubrzo postavljen Vuko Markov Dabović, a u travnju iste godine za potkapetana (Capitano tenente) koji je zapovijedao pukovnikovom satnijom postavljen Vice Blavor. ${ }^{18}$ Koncem kolovoza te iste 1716. godine mletačke su vlasti zabilježile jednu (nama) zanimljivu pojavu u vezi s Bućinom pukovnijom. Naime, providur je zabilježio kako je unovačeno devet satnija pukovnije i kako broj ljudi uvelike prelazi zadanih 500. Međutim, usprkos tomu deseta satnija još nije bila ustrojena i providur je Bući naložio da to u najkraćemu roku mora obaviti. Posve je izgledna pretpostavka kako nitko od podizvođača ugovora o novačenju, koji su se očito s Bućom (Jeronimom) bili dogovorili o novačenju jedne satnije, a koji su uspjeli unovačiti više od traženoga broja od pedeset vojnika po satniji, nije bio spreman ustupiti višak vojnika (novačenje vojnika u pravilu je iziskivalo troškove i država je za to često davala predujam) kako bi Buća ustrojio desetu satniju i odredio joj zapovjednika. ${ }^{19}$

Nema sumnje kako je ovaj vojno-poduzetnički uspjeh, zajedno s njegovim starijim zaslugama, pridonio odluci mletačkih vlasti da Jeronima Buću u ožujku 1717. godine promaknu u visoki čin vojnoga bojnika vojske (Sargente maggiore di battaglia). ${ }^{20}$ Tom je prilikom zabilježeno kako Jeronim ima čin pukovnika $\mathrm{i}$ nadintendanta, kao i naslov kavaljera, kako je vojnu karijeru u dječačkoj dobi započeo kao kapetan talijanskoga pješaštva, a potom postao kapetan konjaničke satnije Croati a cavallo. Nadalje, istaknuo se u Drugome morejskom ratu u bitkama za Sinj, Herceg Novi, Ulcinj i u borbama u dolini Neretve, a nakon rata bio je angažiran na mletačkim talijanskim posjedima. Spis ističe i kako je nakon smrti bojnika Ivana Antuna Bolice (Bolizza) Jeronim preuzeo njegove poslove od kojih je vrlo bio onaj održavanja stalne korespondencije s mletačkim poslanikom u Carigradu. Po izbijanju novoga rata angažirao se u privlačenju stanovnika na stranu Republike te novačenjem spomenute pukovnije Oltramarina. Osim toga, navodi se, Jeronim je u mletačku vojsku uvrstio i vlastite sinove - Franju kao kapetana konjaništva i Stjepana kao pješačkoga pukovnika. Uz prestižan čin bojnika Jeronim je nagrađen i godišnjom plaćom od osamsto dukata. ${ }^{21}$

Godine 1717. Jeronimov je brat Franjo, inače reformirani kapetan, postavljen za guvernadura Risna, prilikom čega je providur zabilježio kako je tu službu već bio obavljao. ${ }^{22}$ Vjerojatno je Tripun Buća, koji je početkom 1732. godine postao bojnik pješačke pukovnije Vicka Burovića, bio njegov sin (prilikom promaknuća

\footnotetext{
${ }^{18}$ HR-DAZD-1-GPDA-kut. 81, str. 203-206, 236.

${ }^{19}$ HR-DAZD-1-GPDA-kut. 81, str. 350v.

${ }^{20}$ Riječ je o činu koji je u mletačkoj vojnoj hijerarhiji bio odmah ispod generalskih činova i otprilike bi odgovaro činu brigadnoga generala kojega mletačka vojna nomenklatura nije poznavala. Opširnije o tomu vidi u: Markulin, "Mletačka vojna organizacija", 62-64.

${ }^{21}$ HR-DAZD-1-GPDA-kut. 87, str. 2-3.

${ }^{22}$ HR-DAZD-1-GPDA-kut. 87, str. 44.
} 
providur je zapisao kako je Tripun nećak proslavljenoga bojnika vojske kavaljera Jeronima Buće). ${ }^{23}$

Godine 1718. generalni providur Alvise Mocenigo unaprijedio je kapetana konjaništva Franju Buću, Jeronimova sina, zbog zasluga u ratu u čin bojnika konjaništva (titolo col rango di sargente maggiore de Croati a cavallo), ali bez povećanja kapetanske plaće. ${ }^{24}$ Franjo Buća je nakon okončanja posljednjega mletačkoosmanskog sukoba nastavio vojnu karijeru u mletačkoj vojsci napredujući do najviših vojnih činova. Od 1725. do početka četrdesetih godina 18. stoljeća djelovao je u činu bojnika u postrojbi kojom je zapovijedao zadarski plemić i pukovnik Lujo Detriko (Detrico). ${ }^{25}$ Godine 1764. obavljao je službu nadintendanta svega mletačkog konjaništva u Dalmaciji i Boki te je imao prestižan čin bojnika vojske (Sargente maggiore di battaglia), a generalni ga je providur Pietro Michiel postavio za guvernadura utvrde Knin, dok je iduće godine postavljen za guvernadura vojske u Kotoru. ${ }^{26} \mathrm{U}$ idućim je godinama Franjo Buća promaknut u generalski čin - 1775. godine ima čin sargente generale. ${ }^{27}$ Bio je to nesvakidašnji uspjeh koji je postiglo svega nekoliko pripadnika dalmatinske i bokeljske društvene elite $\mathrm{u}$ mletačkoj vojnoj službi tijekom postojanja Mletačke Republike. ${ }^{28}$

Stjepan Buća, Franjin brat, s druge je strane nastavio zapovijedati svojom pješačkom pukovnijom tijekom tridesetih i četrdesetih godina 18. stoljeća. U to je vrijeme vojnu službu u svojstvu kadeta započeo i Stjepanov sin Antun. ${ }^{29}$ Godine 1742. stekao je čin zastavnika upravo u očevoj pukovniji. Prema spisima mletačke

\footnotetext{
${ }^{23}$ HR-DAZD-1-GPDA-kut. 102, str. 179-179v.

${ }^{24}$ HR-DAZD-1-GPDA-kut. 87, str. 115v.

${ }^{25}$ Lovorka Čoralić, "Zadarski patricij Lujo Detriko (1672. - 1749.) - zapovjednik hrvatske konjice (Cavalleria Croati)", Zbornik Odsjeka za povijesne znanosti Zavoda za povijesne i društvene znanosti HAZU 32 (2014): 104-106; Čoralić, Katušić,“Kotorski plemići Frano Buća, Gabrijel Vraćen i Nikola Paskvali”, 253-258, 265-268; Markulin, "Mletačka vojna organizacija”, 126, 201.

${ }^{26}$ HR-DAZD-1-GPDA-kut. 159, str. 195, 249. Nama se vrlo izglednom čini pretpostavka kako je čitavo vrijeme riječ o istome Franji Bući, sinu bojnika vojske Jeronima. Inače, to se u navedenim spisima nigdje ne eksplicira. Da li je ipak riječ o dvojici pripadnika obitelji Buća istoga imena vremenski dijelom podudarajuće vojne karijere zasigurno će otkriti neka buduća istraživanja koja se isključivo odnose na Franju Buća. Budući da isti nije središnji protagonist ovoga rada, autori nisu smatrali da je to pitanje prijeko potrebno zasebno razrješavati.

${ }^{27}$ HR-DAZD-1-GPDA-kut. 183, str. 39.

${ }^{28}$ Repubblica Italiana (dalje: RI) - Archivio di Stato di Venezia (dalje: ASVe) - fondo 0715 - Inquisitori sopra l'amministrazione dei pubblici ruoli (dalje: RI-ASVe-0715-Inquisitori ... pubblici ruoli, Cavalleria Croati, b. 782-786. Reggimento Francesco Bucchia, (1757. - 1776.). Dio njegove obitelji bio je nastanjen u Mlecima, odakle potječe i oporuka koju je 1780. godine dala načiniti Franka Buća. O ogranku obitelji Buća u Mlecima vidi i u Lovorka Čoralić, "Život i djelovanje kotorskih patricija u Mlecima od 16. do 18. stoljeća", Radovi Zavoda za hrvatsku povijest Filozofskog fakulteta Sveučilišta u Zagrebu 31 (1998): 134-137. ${ }^{29}$ O specifičnoj ulozi čina kadeta, kao polazišta vojne karijere društvenih elita u profesionalnim postrojbama mletačke vojske u 18 . stoljeću, u vrijeme kada je država na uštrb privatne inicijative nastojala učvrstiti svoju kontrolu nad vojnom organizacijom, opširnije vidi u: Lovorka Čoralić, Nikola Markulin, "Kotorski plemić Benedikt Paskvali (1704. - 1790.) - zapovjednik mletačkih prekomorskih pješačkih postrojbi", Acta Histriae 26 (2018), br. 2: 393-428.
} 
vojne administracije služio je na svim mletačkim posjedima (Italija, Dalmacija i Levant), na mletačkim brodovima koji su plovili po Sredozemlju, ali i Atlantiku (do Britanskoga otočja), a istakao se i u vrijeme izbijanja zaraznih bolesti. Godine 1768. promaknut je u kapetana pješačke satnije Oltramarina..$^{30}$ Antun se spominje i u činu potpukovnika na samome zalazu Serenissime, a bio je (1793.) djelatan u postrojbi pješačkoga pukovnika Jakova Crnice. ${ }^{31}$

\section{Pješačka pukovnija Stjepana Buće (1715. - 1741.): zapovjednici satnija i vojno ljudstvo}

Na osnovi sačuvanih podataka iz Državnoga arhiva u Mlecima (spomenuti fond Inquisitori sopra l'amministrazione dei pubblici ruoli) kronološkim ćemo redom, prema pojedinim pratećim razdobljima, ukazati na sastav Bućine pukovnije i njezinih pripadajućih satnija, posebice se obazirući na njegovu osobnu satniju. ${ }^{32}$

Prvo prateće razdoblje, držeći se slijeda rasporeda arhivskoga gradiva, datira od 1715. do 1726. godine. ${ }^{33}$ Kroz to je vrijeme u pukovniji zabilježeno (ne nužno istovremeno) četrnaest satnija kojima su zapovijedali (uz osobnu satniju Stjepana Buće) sljedeći časnici: ${ }^{34}$ kapetan Kamilo Bečić (Kotor, 1715.), potpukovnik (Tenente colonnello) Martin Bogetić (Mleci, 1724; Kopar 1725.), kapetan Jovo Đurđević (Split, 1715.), pukovnik Josip Antun Fanfonja/Fanfogna (Mleci, 1725.), kapetan Antun Marković (Mleci, 1721.; Bergamo, 1723.; Bergamo, 1724.; Bergamo, 1726.), ${ }^{35}$ kapetan Ivan Matija Mihovilović (Cremona, 1722.; Mleci, 1725.), pukovnik Ivan Napadić (Mleci, 1722.), potpukovnik Jakov Navarin (Krf, 1717.;Mleci, 1719.), kapetan Jakov Paskvali (Kotor, 1715.), potpukovnik Josip Preradović

\footnotetext{
${ }^{30}$ HR-DAZD-1-GPDA-kut. 165, str. 154.

${ }^{31}$ RI-ASVe-0715-Inquisitori ... pubblici ruoli, Oltramarini, b. 686. Reggimento Pietro Rado (1770. 1777.); RI-ASVe-0715-Inquisitori ... pubblici ruoli, Oltramarini, b. 694B. Reggimento Giacomo Cernizza (1793.).

${ }^{32} \mathrm{Na}$ osnovi gradiva u Državnome arhivu u Zadru spoznaje o djelovanju Stjepana Buće nisu opsežne. Stoga je težište rada, kako je prethodno i kazano, usmjereno na ustroj i strukturu njegove pukovnije i osobnih satnija, a ti su dokumenti pohranjeni u središnjoj mletačkoj pismohrani kao dio spomenutoga fonda Inquisitori sopra l'amministrazione dei pubblici ruoli.

${ }^{33}$ RI-ASVe-0715-Inquisitori ... pubblici ruoli, Oltramarini, b. 501. Reggimento Bucchia Steffano e Antonio (1715. - 1726.). Ovdje je potrebno napomenuti da svi svežnjevi koji će ovdje biti raščlanjeni u naslovu imaju - uz Stjepanovo - i ime Antuna Buće. Međutim, izravnim uvidom u sačuvane spise opažamo da nijedna satnija nije bila pod Antunovim vodstvom niti je potonji u tome razdoblju sa Stjepanom dijelio zapovjedništvo nad pukovnijom. Također, popis Bućine osobne satnije iz 1724. godine, koja bi kronološki ulazila u ovaj svežanj gradiva, očito je pogreškom arhivista prebačena u b. 510. Taj popis, načinjen u Mlecima 30. travnja 1724., nakon povratka satnije iz Brescije, nismo (zbog prevelike istovjetnosti s popisima iz ranijih svežnjeva) držali potrebnim uvrstiti u podrobnije razmatranje.

${ }^{34}$ Ovdje donosimo pregled po svakome zapovjedniku satnije. Navodi se zapovjednikov čin, njegovo ime i prezime te mjesto i godina nastanka popisa. Zapovjednici satnija navode se abecednim redom.

${ }^{35}$ O uglednom vojnom inženjeru i pukovniku Antunu Markoviću vidi u: Lovorka Čoralić, Nikola Markulin, "Vojni inženjer Antun Marković (u. 1767.) i njegova pješačka pukovnija", Radovi Zavoda za povijesne znanosti HAZU u Zadru 60 (2018): 167-204.
} 
(Mleci, 1721; Udine, 1723; Palmanova, 1724.), kapetan Rade Lukov (Split, 1715.), kapetan Marko Raffaelli (Split, 1715.) i kapetan Vuko Markov (Split, 1716.). Osobna satnija pukovnika Buće u ovome se razdoblju bilježi četiri puta, a riječ je u popisima nastalim u Splitu (1715.), Cremoni (1723.) i Bresciji (1724. i 1725.). Za ovu prigodu odabran je najstariji popis, onaj načinjen u Splitu tijekom trajanja Drugoga morejskog rata (datiran je na 25. siječnja 1715.). ${ }^{36}$ Satniju je u svojemu osnovnom sastavu činilo 57 časnika, dočasnika te običnih vojnika, a kada je riječ o časničkom i dočasničkom kadru, tu su uz pukovnika Buću, potkapetan $(\mathrm{Ca}$ pitan tenente) Vicko Blavor, narednik (Sargente) Krsto Nikov i kaplar (Caporal) Pavo Josov, dočim se kao glazbena pratnja (bubnjari/Tamburo) ${ }^{37}$ bilježe Marko Milošev i Marko Nikov, obojica Crnogorci s područja Cetinja odnosno Njeguša. Zavičajno podrijetlo vojnika u ovoj satniji gotovo je redovito navedeno, a za veliku većinu možemo s velikom vjerojatnošću držati da su Crnogorci. U vrlo malenome broju to su Bokelji (Kotor, Orahovac), koji često potječu s područja Grblja, Pobora i Brajića, a najčešće njihov uži zavičaj treba tražiti na području Cetinja (Gornja Zaljut, Vrba), Njeguša, u Katunskoj nahiji (Pješivci, pleme Cuce) ili kraj današnje Podgorice (Gradac, Ubli). Iz ovoga su popisa naknadno prekrižena (vjerojatno zbog prijelaza u drugu postrojbu, dezertiranja ili smrti) 23 vojnika, ali je u satniju prispjelo 34 novih pješaka (od kojih su popisivači s vremenom prekrižili trojicu). U dočasničkomu se dijelu po prvi puta bilježe Pavao iz Zadrime (na području Skadarskoga jezera), kaplar Jovo Vučićev iz Herceg Novoga te mornar (Mariner) Tripun Muzača/Muzzachia iz Prčanja. Iako i ovdje prevladavaju vojnici iz unutrašnjosti Crne Gore, primjetan je porast Bućinih pješaka iz Boke (Herceg Novi, Kotor, Kruševice, Prčanj i Risan) i s područja Paštrovića (Kaštel Lastva odnosno današnji Petrovac te Sveti Stefan). Sveukupno promatrajući zavičajno podrijetlo časnika, dočasnika i običnih vojnika iz Bućine satnije i uzimajući u obzir oba popisa kao i činjenicu da svi vojnici nisu istodobno činili dio njezina vojnoga ljudstva, razvidna je premoć vojnika iz Crne Gore (51,65 \%). Na vojnike čije podrijetlo također vjerojatno jest Crna Gora, ali ono nije izrijekom iskazano, otpada 25,27 \%, dočim na Bokelje 16,48 \%. Naposljetku, s područja Hercegovine (Grahovo, Trebinje) dolazilo je 4,40\% vojnika, a na one iz Albanije (područje Skadra) samo 2,20 \% (vidi: Grafikon 1). Kao što je to uobičajeno u primjeru većine popisa, na početku su navedene plaće vojnika prema njihovim činovima. Pukovnik je za službu dobivao mjesečno od države četrdeset dukata, potkapetan (Capitan tenente) četrnaest dukata, dočim su plaće zastavnika (Alfier), narednika, kaplara i običnih vojnika (Fanti) iskazane u lirama (60 - 48 - 36 - 30 lira).

\footnotetext{
${ }^{36}$ Ovdje je potrebno napomenuti da su - uz Bućinu - još četiri satnije faktički istovremeno popisane u Splitu te je njihovo vojno djelovanje očito bilo vezano uz dalmatinski i hercegovački dio bojišnice.

${ }^{37}$ O glazbenoj pratnji u mletačkim prekojadranskim kopnenim postrojbama vidi u: Lovorka Čoralić, Vjera Katalinić, Maja Katušić, "Bubnjari, timpanisti, trubači i pifaristi: glazbena pratnja u mletačkim prekojadranskim kopnenim postrojbama u 18. stoljeću", Arti musices 47 (2016), br. 1-2: 27-78.
} 
Grafikon 1. Zavičajno podrijetlo vojnoga ljudstva u osobnoj satniji Stjepana Buće prema popisu načinjenome u Splitu 1715. godine

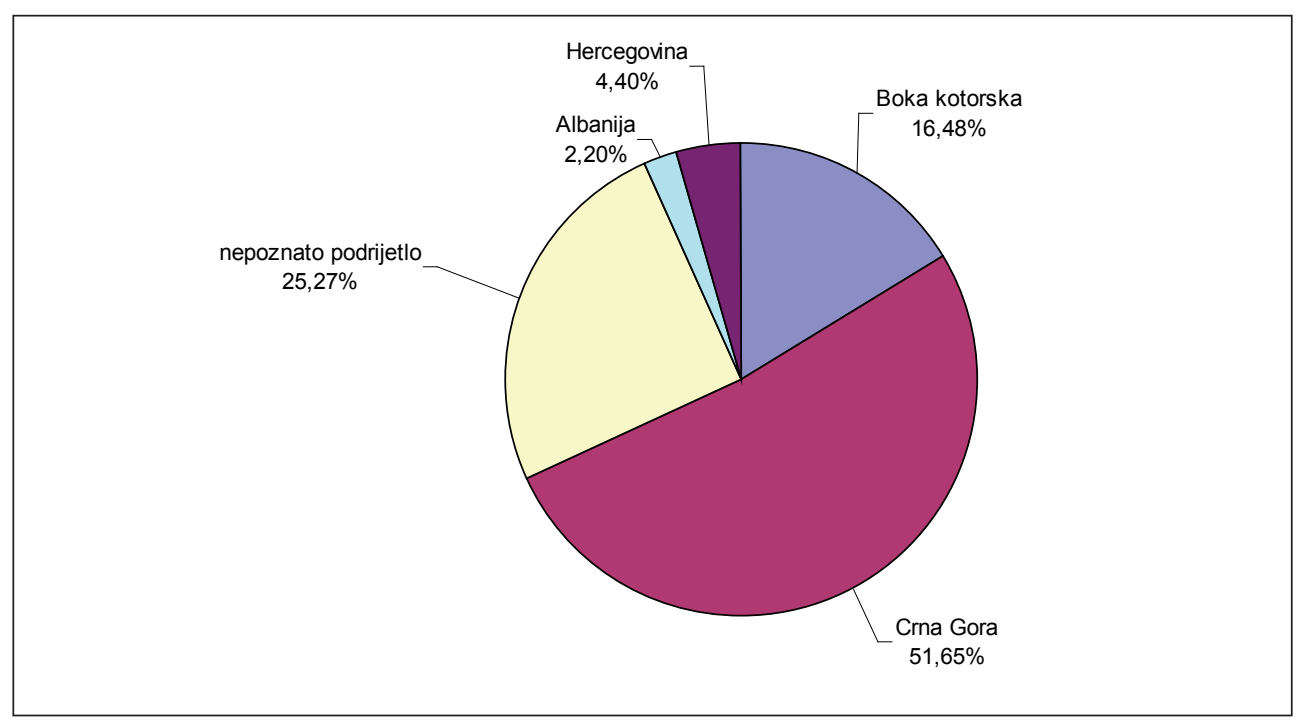

Sljedeće prateće razdoblje djelovanja pukovnije Stjepana Buće odvijalo se od 1726. do 1728. godine. ${ }^{38}$ Riječ je o poratnome, mirnodopskome vremenu kada su satnije u pravilu smanjivane, kako njihovim ukupnim brojem unutar pukovnija, tako i brojem vojnika unutar njih zasebno. U ovome razdoblju Bućina je pukovnija brojila sedam satnija, a njihovi su časnici bili: potpukovnik Martin Bogetić (Mleci, 1727. - 1728., ukupno pet popisa), kapetan Franjo Makedonija/Macedonia (Palmanova i Zadar, 1726.), kapetan Antun Marković (Bergamo, 1727. i 1728.), kapetan Ivan Matija Mihovilović (Udine, 1727.), pukovnik Ivan Napadić (Mleci, 1727. i 1728., ukupno pet popisa), potpukovnik Josip Preradović (Palmanova, 1726.). Razmještaj satnija bio je, kao što je iz prethodno navedenoga razvidno, područje mletačke terraferme, a plaće časnika, dočasnika i običnih vojnika nisu bile promijenjene, kao što to neće biti slučaj niti u popisima tijekom idućih godina.

Raspolažemo s četiri popisa koji se odnose na Bućinu osobnu satniju. Načinjeni su 1726. (Cremona), 1727. (Brescia) i 1728. godine (Bergamo i Brescia). U ovoj ćemo raščlambi posebnu pozornost posvetiti popisu nastalome u Bresciji 4. kolovoza 1727. godine. ${ }^{39}$ Prema ovome popisu osnovni dio ljudstva činilo je 38 časnika, dočasnika i običnih vojnika, a u dijelu koji se odnosi na časnički kadar i

\footnotetext{
${ }^{38}$ RI-ASVe-0715-Inquisitori ... pubblici ruoli, Oltramarini, b. 502. Reggimento Bucchia Steffano e Antonio (1726. - 1728.).

${ }^{39}$ RI-ASVe-0715-Inquisitori ... pubblici ruoli, Oltramarini, b. 502, Reggimento Bucchia Steffano e Antonio (1726. - 1728.). Odabran je upravo ovaj popis jer su podaci o vojnicima najkompletniji te jer se u drugim popisima opaža izrazito ponavljanje istoga vojnog ljudstva.
} 
glazbenu pratnju zabilježeni su, uz pukovnika Buću, potkapetan Franjo Kažotić, zastavnik Pavao iz Zadrime, narednik Krsto Nikov, narednik u pričuvi (Sargente riformato) Stojan Milić, kaplari Matija Brsaljević iz Vrgorca i Ilija Raićev te bubnjar Franjo Pišenić. I u ovome primjeru postotnim udjelom prednjače vojnici iz unutrašnjosti Crne Gore odnosno s područja Grblja, Njeguša, Banjana i drugih $(31,58 \%)$. Iz Boke (poglavito je riječ o gradu Kotoru) potjecalo je $18,42 \%$ vojnika, iz Dalmacije njih 13,16 \% (Šibenik, Trogir, Vrgorac, Zadar), dočim je znatan postotak (21,05 \%) otpadao na osobe neiskazanoga matičnog podrijetla. Iz Albanije su popisivači zabilježili 5,26 \% vojnika, jednako koliko i iz Istre (Poreč i općenita oznaka Istria). Naposljetku, jedan je vojnik dolazio iz sjeverne Hrvatske (Senj $-2,63 \%)$, a zabilježen je i jedan pojedinac iz Trsta (2,63 \%). ${ }^{40}$ (Vidi: Grafikon 2).

Grafikon 2. Zavičajno podrijetlo vojnoga ljudstva u osobnoj satniji Stjepana Buće prema popisu načinjenome u Bresciji 1727. godine

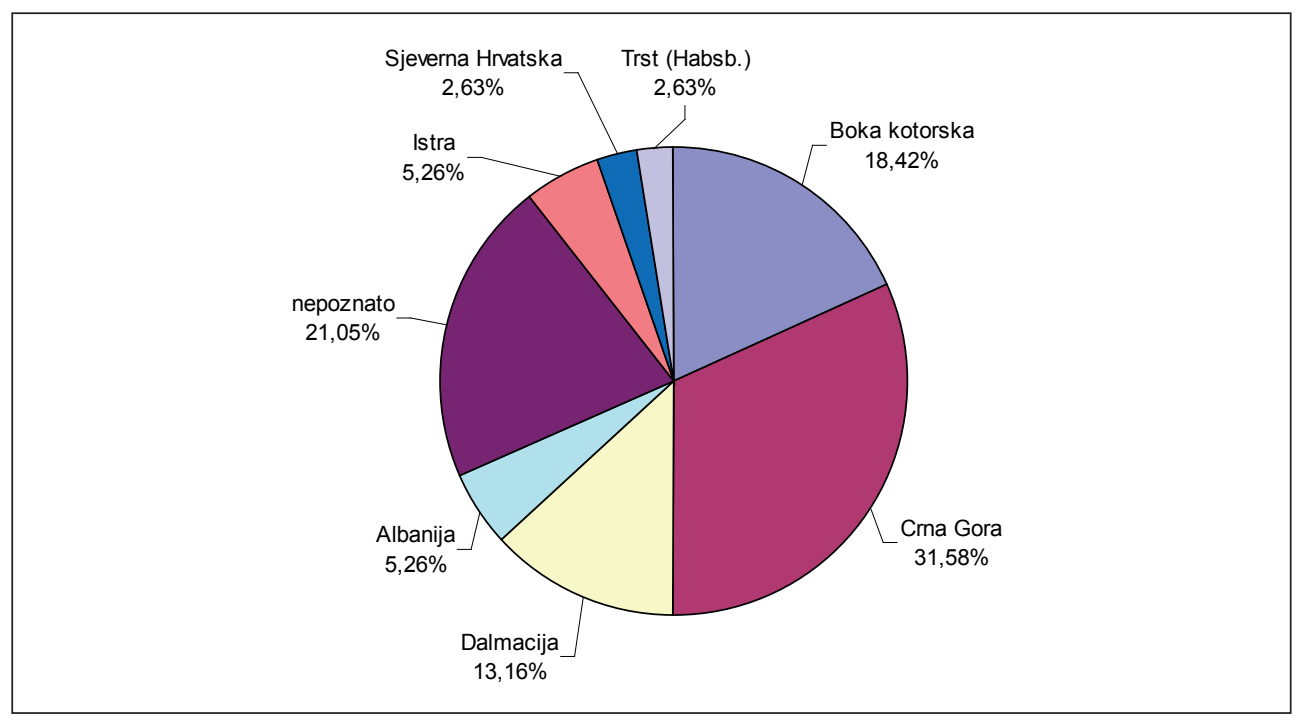

Popisivači su bilježili i neke tjelesne karakteristike vojnika. Tako je najmlađi vojnik zasigurno bio bubnjar Franjo Pišenić, koji se definira kao dječak (putto) malenoga rasta (piccolo). Najstariji je vojnik u satniji bio Crnogorac Ivan Perov (63 godine), a sveukupno je prosječna dob ovdje razmatranih vojnika iznosila 28 godina. Nadalje, kao i u brojnim drugim primjerima istraživanja mletačkih prekojadranskih kopnenih postrojbi, popisivači su vojnike najčešće percipirali kao osobe srednjega rasta (ordinario, comun). Iznimke ovim, prosječno visokim

\footnotetext{
${ }^{40}$ Iako su i Senj i Trst pripadali istoj, austrijskoj državi, radi preglednosti i boljega razumijevanja ovdje su u statističkome izračunu i grafičkome prikazu oni ipak odvojeni.
} 
i dobro građenim pješacima, vrlo su rijetke. To su, kada je riječ o kategoriji onih nižega stasa (piccolo, basso), primjerice bili već spomenuti bubnjar Pišenić, Milutin Ivanov iz plemena Cuce, Juraj Kočevac iz Trsta, Tripun Paskvalović i Niko Stijepov iz Kotora i drugi. Popisivači nisu zabilježili niti veći broj visokih (alto) vojnika, odnosno onih krupne građe (grande). Među njima su kaplar iz Vrgorca Matija Brsaljević te vojnici Ivan Antunov iz Istre, Pero Nikolin iz Herceg Novoga, Stijepo Radović i Joko Stipanov iz Paštrovića te Stipan Vukov s grbaljskoga područja. Boja kose sljedeća je opažena tjelesna značajka upisana za veći dio vojnika. I ovdje prevladavaju stereotipi te je većina vojnika procijenjena kao castagno (smeđokosi), a za neke je dodano da su kovrčavi (rizzo). Uz ove tjelesne osobine popisivače su doimali i brkovi (mostachi) kod dijela vojnika te su to u primjeru kaplara Ilije Raićeva i vojnika Petra Vukadinovića izrijekom i zabilježili, pri čemu u opisu potonjega stoji mostachi grandi. Predstavljanje vojnika najčešće je završavalo općim dojmom o njihovoj puti, a u pravilu su opisivani kao svjetloputi (chiaro) ili tamnoputi (nero). Na kraju ovoga razmatranja jednoga od pratećih razdoblja postojanja Bućine pukovnije te provedene raščlambe sastava njegove osobne postrojbe iz 1727. godine potrebno je napomenuti da u ovome popisu nema prekriženih vojnika kao ni dopisivanja novih pješaka.

Sljedeće razdoblje koje je $u$ fokusu našega istraživanja obuhvaća trogodište od 1728. do 1731. godine ${ }^{41}$ Bućina je pukovnija brojila tada osam satnija, a kao zapovjednici zabilježeni su: potpukovnik Martin Bogetić (Mleci, 1728. - 1729., ukupno četiri popisa; Rovigo, 1730.), kapetan Franjo Makedonija (Palmanova, 1729.; Mleci, 1730.), kapetan Antun Marković (Brescia, 1729.; Legnago, 1729. i Verona, 1731.), kapetan Ivan Matija Mihovilović (Udine, 1728.; Mleci, 1730.), pukovnik Ivan Napadić (Mleci, 1729.), potpukovnik Josip Preradović (Udine, 1729. i 1730.) i bojnik (Sargente maggiore) Petar Juraj Preradović (Mleci, 1728.; Padova, 1728.; Udine, 1730.). Kada je riječ o postrojbi pukovnika Buće, sačuvan nam je samo popis načinjen 10. listopada 1729., najvjerojatnije u Mlecima odnosno na Lidu. Satnija je brojila 75 časnika, dočasnika i vojnika od kojih je njih deset naknadno prekriženo. Velik dio vojnika ponavlja se iz prethodnih popisa te su sukladno tome najčešće iz unutrašnjosti Crne Gore. ${ }^{42}$ Također, popisivači su za najveći dio vojnika pisali istovjetnu godine starosti kao i u popisu načinjenome prije dvije godine, a njihova statura i boja kose također su u najvećoj mjeri podudarajuće. Uz pukovnika Buću časnički i dočasnički kadar činili su još i: kapetan u pričuvi Franjo Fanfonja (Fanfogna), potkapetan Maksim Obrić, poručnik u pričuvi (Tenente riformato) Giuseppe Metralli, zastavnik Tripun Buća, ${ }^{43}$ zastavnik u pričuvi (Alfier

${ }^{41}$ RI-ASVe-0715-Inquisitori ... pubblici ruoli, Oltramarini, b. 503. Reggimento Bucchia Steffano e Antonio (1728. - 1731.).

${ }_{42}$ To je ujedno i razlog što podrobniju rašlambu zbog ograničenosti prostora nećemo ponavljati.

${ }^{43}$ Tripun Buća u kasnijemu se razdoblju (od 1736.) bilježi kao bojnik u pješačkoj postrojbi Bokelja Tri- 
riformato) Antun Fedrigo, narednik Krsto Nikov, narednici u pričuvi (Sargente riformato) Pietro Dupre, Stojan Milić i Ivan Picinalli te kaplari Matija Brsaljevićc ${ }^{44}$ Ilija Raićev. Bubnjar je bio dječak Franjo Pišenić, a kao pifaristi (Piffaro) spominju se Scipion Ferrante i Karlo Paleit iz Kotora.

$\mathrm{U}$ godinama koje su uslijedile dolazi do manjih promjena u sastavu pojedinih satnija u pukovniji Stjepana Buće. ${ }^{45}$ Promjene se nisu osobito odrazile na sam časnički dio ljudstva te su zapovjednici pojedinih satnija uglavnom isti kao i u prethodnim popisima. Satnijama u pukovniji Buća početkom tridesetih godina 18. stoljeća zapovijedali su: pukovnik Josip Antun Fanfonja (Hvar, 1733.) kapetan Juraj Klarić (Mleci, 1731.; Verona, 1731.), kapetan Franjo Makedonija (Mleci, 1731., ukupno dva popisa), kapetan Antun Marković (Mleci, 1731. i 1732., ukupno tri popisa), kapetan Ivan Matija Mihovilović (Verona, 1731. - 1732., ukupno tri popisa), pukovnik Ivan Napadić (Zadar, 1733.), potpukovnik Josip Preradović (Udine, 1731.) i bojnik Petar Juraj Preradović (Udine, 1731., ukupno dva popisa).

Osobna satnija Stjepana Buće popisana je u Bergamu 18. travnja 1731. godine. ${ }^{46}$ Brojila je šezdeset časnika, dočasnika i običnih vojnika, koji se u velikoj mjeri ponavljaju u odnosu na prethodni popis. ${ }^{47}$ Također, iako su se zbile određene promjene u postotnim omjerima zavičajnoga podrijetla Bućinih vojnika, one ipak u velikoj mjeri odražavaju stanje iz prethodnih godina. Prema ovome popisu ipak prednjače Bokelji (36,67 \%), ponajprije iz glavnoga grada Kotora, ali i iz Herceg Novoga i s poluotoka Luštice. Unutrašnjost Crne Gore zastupljena je vojničkim ljudstvom s 26,67 \%, a kao i u prethodnim raščlambama - uz opće nazive Monte Negro ili Zeta - bilježe se i vojnici s područja Njeguša te iz plemena Banjani i Cuce. Na vojnike kojima podrijetlo nije pobliže označeno otpada 16,67 \%, dočim na Dalmatince (Zadar i Trogir) 6,67 \%. Sve ostale zavičajne skupine zastupljene su u pokojemu, često samo pojedinačnome primjeru. Istrani (Kopar) zabilježeni su s 3,33 \%, Albanci s 3,33\%, a na vojnike s područja Dubrovačke Republike, sjeverne Hrvatske, Hercegovine i nekih drugih gradova odnosno regija otpada samo po $1,67 \%$ (vidi: Grafikon 3).

puna Vicka Burovića. RI-ASVe-Inquisitori ... pubblici ruoli, Oltramarini, b. 512. Reggimento Burovich Triffone Vicenzo (1736. - 1737.).

${ }^{44}$ Matija Brsaljević je 22. srpnja 1730. promaknut u čin narednika.

${ }^{45}$ RI-ASVe-Inquisitori ... pubblici ruoli, Oltramarini, b. 504. Reggimento Bucchia Steffano e Antonio (1731. - 1733.).

${ }^{46}$ RI-ASVe-0715-Inquisitori ... pubblici ruoli, Oltramarini, b. 504, Reggimento Bucchia Steffano e Antonio (1731. - 1733.).

${ }^{47}$ Uz pukovnika Buću zabilježeni su i kapetan u pričuvi Franjo Fanfonja, potkapetan Maksim Obrić, zastavnik Tripun Buća, narednik Matija Brsaljević, narednici u pričuvi Pietro Dupre i Stojan Milić, kaplari Petar Pejanov i Ilija Raićev, bubnjar Franjo Pišenić te pifaristi Scipion Ferrante i Karlo Paleit. 
Grafikon 3. Zavičajno podrijetlo vojnoga ljudstva u osobnoj satniji Stjepana Buće prema popisu načinjenom u Bergamu 1731. godine

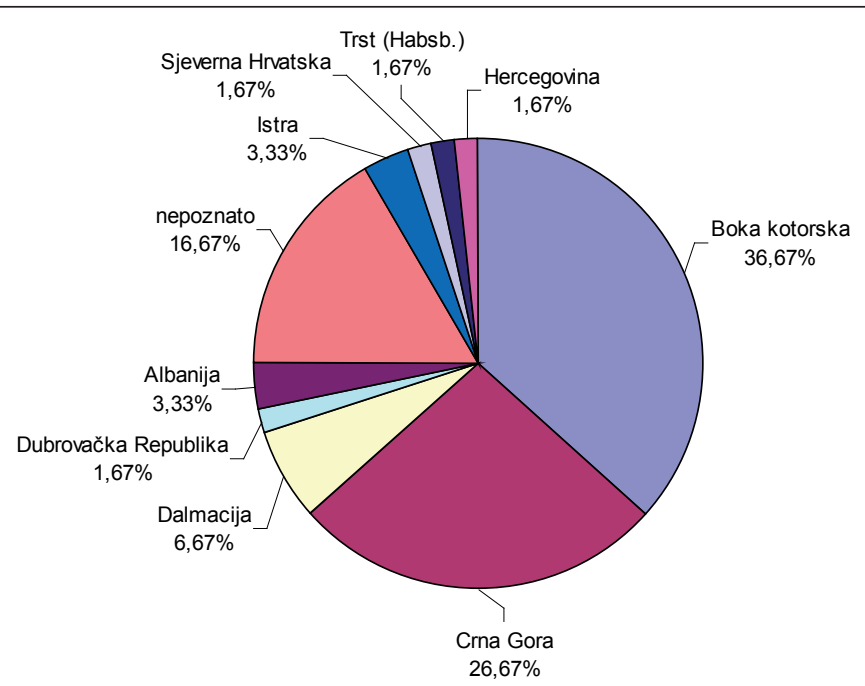

Starost ove skupine vojnika nije redovito navedena, najčešće samo u primjerima novopridošlih pripadnika postrojbe. Kada je riječ o najmlađim vojnicima, to su (svi u dobi od devetnaest godina): Jakov Franov i Marko Antun Pezzi iz Kotora te Stijepo Radov s područja poluotoka Luštice. Novi vojnici Bućine satnije bili su relativno mladi te stoga ne začuđuje podatak da je najstariji - Antun Romić iz Kopra - imao samo trideset godina. Stoga je i njihova ukupna prosječna dob bila tek 22 godine. Sukladno prethodnim opažajima popisivača, ovi su vojnici poglavito osobe srednjega stasa, uz iznimku pokojega vojnika koji je definiran kao visok (primjerice, Prenz Giura iz naselja Livari na području grada Bara, Ivo Jakovljev iz Kotora i drugi) ili nizak (Jakov Franov iz Kotora, Đuro Ivić s područja Grbalj i drugi). Rečeni vojnici najčešće su smeđokosi, a samo su Marko Boškov iz Trebinja, Grbljanin Đuro Ivić i Kotoranin Ivo Jakovljev upisani kao crnokosi (nero, moro). Godine 1733. (najčešće je riječ o drugoj polovici, odnosno o kraju godine) i 1734. načinjeno je još nekoliko popisa vojnika uključenih u satnije Bućine pukovnije. ${ }^{48}$ Za to razdoblje - vjerojatno zbog nesačuvanosti gradiva - ne nalazimo podatke o osobnoj satniji Stjepana Buće, a zapovjednici drugih jedinica bili su već višestruko spominjani: kapetan Juraj Klarić (Mleci, 1733., ukupno tri popisa), kapetan Franjo Makedonija (Mleci i Poreč, 1733.), kapetan Antun Marković (Mleci, 1733., ukupno tri popisa), kapetan Marko Mida (Mleci, 1734.), kapetan Ivan Matija Mihovilović (Polesine i Verona, 1733.), pukovnik Ivan Napadić (Mleci, 1734.),

${ }_{48}$ RI-ASVe-0715-Inquisitori ... pubblici ruoli, Oltramarini, b. 505. Reggimento Bucchia Steffano e Antonio (1733. - 1734.). 
potpukovnik Josip Preradović (Palmanova, 1733.) i bojnik Petar Juraj Preradović (Udine, 1734.).

Sedam je satnija zabilježeno u Bućinoj pukovniji od 1734. do 1736. godine, a njihovi su zapovjednici dobro poznati iz prethodnih popisa. ${ }^{49}$ Isti nam izvor donosi dva popisa Bućine osobne postrojbe. Prvi je popis načinjen u Mlecima 25. listopada 1735., a drugi - koji ćemo ukratko opisati - u Padovi 30. lipnja 1736. godine. Drugi je popis načinjen - zbog pukovnikove bolesti - bez njegove osobne nazočnosti. Vojno ljudstvo brojilo je 81 časnika, dočasnika i običnih vojnika, a velik je broj njih - u odnosu na prethodnih nekoliko popisa istovjetan odnosno nepromijenjen. Mjesta njihova podrijetla su, uz priobalna područja (Bar, Herceg Novi, Kotor, Risan, poluotok Luštica) i unutrašnjost (plemena Banjani, Cuce, Njeguši i druga). također i dijelovi Dalmacije (Korčula, Split, Zadar) i sjeverne Hrvatske (Lika, Senj). Ono što se također može opaziti jest da je dob vojnika određivana površno, odnosno da podaci iz prethodnih popisa ne odgovaraju protoku vremena. Primjerice, Ivan Stanišić iz Kostanjice prema popisu iz 1731. godine imao je 25 godina, a ista se dob spominje i u ovdje raščlanjenome popisu. Isto se odnosi i na Joku Zambellija (u novome popisu nazvan Zambelić), koji je 1731. godine imao 20 godina, a 1736. bio je definiran kao vojnik star 22 godine. Slično se odnosi i na opis njihova tjelesnog izgleda te su uglavnom svi vojnici opisani na isti način kao i u prethodnim popisima. Navedimo ipak neke promjene u sastavu vojnoga ljudstva. Časnički i dočasnički kadar činili su sljedeći vojnici: uz pukov-

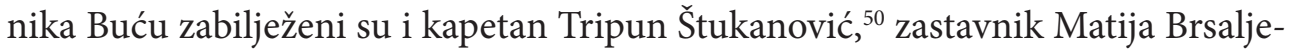
vić (napredovao je iz čina narednika u čin zastavnika), narednik Petar Ivanov iz mjesta Ubli (napredovao iz statusa običnoga vojnika do narednika), kaplari Jovo Radov iz Njeguša, Staniša Milin iz plemena Cuce (napredovao iz statusa običnoga vojnika do narednika) i Vasilj Marijanović iz Knina. Kao dio glazbene pratnje bilježe se već prethodno spomenuti pifarist Karlo Paleit iz Kotora i bubnjar Pavao Markov (nepoznatoga podrijetla). Sveukupno, popis načinjen u Padovi 1736. godine nije bitno različit od prethodnoga. Dio vojnika - koji su popisivani slijedom koji bi u početnome dijelu odgovarao prethodnome popisu, odnosno u kojemu se kao prvi zapisani vojnici bilježe oni koji su već bili prisutni prethodnih godina - istovjetan je i pokazuje kako je djelovanje Stjepana Buće, prema izvorima očito u velikoj mjeri usmjerenog na vojno poduzetništvo - u praksi polučivalo dobre rezultate. Veliki broj vojnika, od kojih se više od polovice ponavlja iz godine u

\footnotetext{
${ }_{49}$ To su kapetan Juraj Klarić (Mleci, 1735.), kapetan Franjo Makedonija (Mleci, 1736. i Bergamo, 1736.), kapetan Ivan Matija Mihovilović (Brescia, 1734. i 1735.), pukovnik Ivan Napadić (Mleci, 1734. i 1736.; Verona, 1735.), potpukovnik Josip Preradović (Palmanova, 1735.; Udine, 1735. - 1736.) i bojnik Petar Juraj Preradović (Mleci, 1735.). Usp.: RI-ASVe-0715-Inquisitori ... pubblici ruoli, Oltramarini, b. 506. Reggimento Bucchia Steffano e Antonio (1734. - 1736.).

${ }^{50}$ O vojnoj karijeri Bokelja Tripuna Štukanovića podrobnije vidi u radu Lovorka Čoralić, Maja Katušić "Peraštanin Tripun Štukanović (+ 1769) - pukovnik mletačkih oltramarina", Anali Zavoda za povijesne znanosti HAZU u Dubrovniku 50 (2012): 385-410.
} 
godinu, ukazuje da je pukovnik imao uspjeha u novačenju vojnika, ali ujedno $\mathrm{i}$ upozorava na mogućnost manipulacije popisima. Na to ukazuju godine starosti vojnika, koje očito ne odgovaraju ranijim popisima i ostavljaju mogućnost da su popisivači jednostavno dio vojnoga ljudstva prepisivali bez provjere njihovih konkretnih podataka. Otuda ponavljanja, neujednačenosti u konkretno iskazanim brojkama te je stoga ovome dijelu izvora - uz njihovu važnost za istraživanje rečenih vojnih postrojbi - u konačnici uvijek potrebno pristupiti s oprezom.

U idućim godinama opažamo ipak neke promjene u sastavu satnija Bućine pukovnije. U razdoblju od 1737. do 1738. godine u pukovniji je djelovalo devet satnija, ${ }^{51}$ a njima su - uz osobnu postrojbu pukovnika Buće - zapovijedali sljedeći časnici: kapetan Ivan Valerijan Ambati (Mleci, 1737.), kapetan Anđelo Franko (Mleci, 1737.), kapetan Juraj Klarić (Mleci, 1737., ukupno dva popisa), kapetan Franjo Makedonija (Kopar, 1738.), ${ }^{52}$ pukovnik Ivan Napadić (Mleci, 1737.), potpukovnik Josip Preradović (Palmanova i Mleci, 1737.), bojnik Petar Juraj Preradović (Palmanova i Mleci, 1737.) i bojnik Juraj Sablić (Mleci, 1737. - 1738., ukupno pet popisa). Većina satnija popisana je u Mlecima odnosno na Lidu ili u nekim drugim uporištima Mletačke Republike duž terraferme, a u pravilu su nakon načinjenoga popisa upućivane $a$ Levante. Isti je slučaj i s Bućinom osobnom satnijom, koja je popisana u Mlecima 24. travnja 1737. i potom odaslana na barche armate koje su djelovale na Levantu. Osnovni sastav Bućine postrojbe činilo je 57 časnika, dočasnika ${ }^{53}$ i običnih vojnika. Naknadno je prekriženo šesnaest vojnika, a na njihovo je mjesto prispjelo devetnaest novih vojnika, među kojima su zastavnik Juraj Karađija, narednik Franjo Lučić iz Senja, mornari (vjerojatno grčkoga podrijetla) Janni Anifondi i Stavervachi Scordilli te pifarist Andreas Gligoropulo. Novopridošla posada vojnoga broda nije se, prema svemu sudeći, dugo zadržala jer su od devetnaest novih vojnika njih devetorica uskoro prekrižena. Kako je ova postrojba trebala svoju službu obavljati duž mletačkih pomorskih stečevina na području Grčke, a upravo su prekriženi ovdje navedeni grčki mornari, moguće je pretpostaviti da Bućina satnija nije naposljetku ondje bila upućena ili su grčki mornari zamijenjeni bokeljskim znalcima navigacije. Raščlamba podataka o zavičaju Bućine postrojbe namijenjene za Levant (promatrani su svi vojnici koji su zabilježeni u popisu bez obzira jesu li su dio osnovnoga sastava ili su prispjeli naknadno) odaje nam zanimljive rezultate (vidi: Grafikon 4). Po prvi puta, odnosno od prvoga sačuvanog popisa, u ovoj satniji prednjače Dalmatinci (25,00 \%). Najčešće su potjecali iz Zadra, a tek u manjemu broju primjera iz gradova i manjih mjesta duž dalmatinske obale (Biograd na Moru, Hvar, Split)

\footnotetext{
${ }^{51}$ RI-ASVe-0715-Inquisitori ... pubblici ruoli, Oltramarini, b. 507. Reggimento Bucchia Steffano e Antonio (1737. - 1738.).

${ }^{52}$ Franjo Makedonija je u ovome je razdoblju prestao djelovati (moguće zbog smrti ili preuzimanja nove dužnosti u drugoj pukovniji), a čin kapetana i vođenje satnije preuzeo je Nikola Račić.

${ }^{53}$ Uz pukovnika Buću u časničkome i dočasničkome dijelu vojnoga ljudstva zabilježeni su i potkapetan Tripun Štukanović, zastavnik Matija Brsaljević, narednik Petar Ivanov te kaplari Staniša Milin, Marko Nikolin i Jovo Radov, a kao glazbena pratnja bubnjar Pavao Mano i pifarist Karlo Paleit.
} 
ili iz zaleđa (Biljane, Biovičino Selo, Cetina, Raštević). Jednak se postotni omjer (po 18,42\%) odnosi na vojnike nepoznatoga odnosno neiskazanoga podrijetla kao i na one s područja Boke (Herceg Novi, Kostanjica te osobito često Kotor). Zatim, Njeguši, Cuce okolica Podgorice i područje uz Skadarsko jezero, odakle je dolazilo $13,16 \%$ crnogorskih vojnika, dočim su sve ostale regionalne skupine zastupljene u relativno malenome postotnom omjeru. To su područje sjeverne Hrvatske (Karlobag, Lika, Senj) sa 6,58 \%, Istra s 5,26 \%, Grčka s 3,95 \%, Apeninski poluotok s 2,63 \% te na kraju Hercegovina (Trebinje), Albanija, Dubrovačka Republika, Kranjska i kao kuriozum koji vrijedi izdvojiti u zasebnu skupinu - Beč s po $1,32 \%$ vojnika.

Grafikon 4. Zavičajno podrijetlo vojnoga ljudstva u osobnoj satniji Stjepana Buće prema popisu načinjenome u Mlecima (Lido) 1737. godine

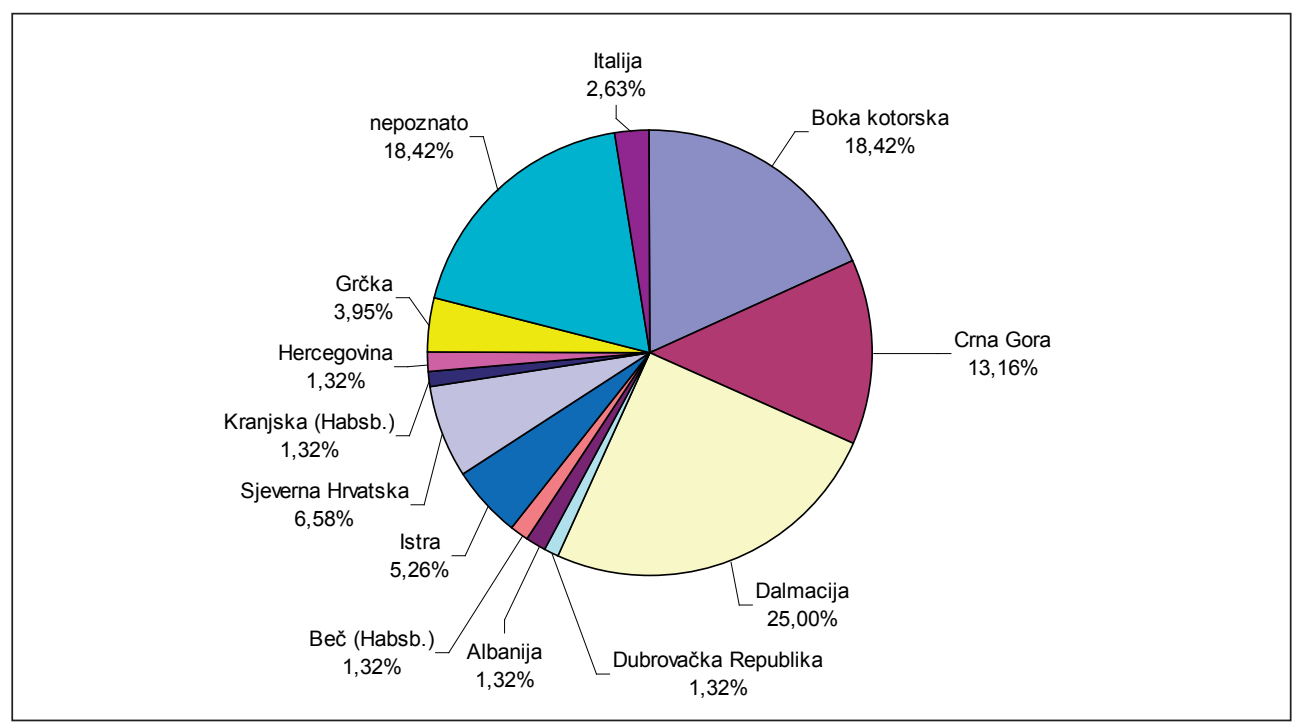

Kada je riječ o dobi i tjelesnim osobinama vojnika, opažamo da su takvi podaci često navedeni, ali - uzevši u obzir prethodno izrečenu napomenu o nesustavnosti popisivanja pri procjeni dobi kao i stereotipnost pri prikazu tjelesnoga izgleda vojnika - te je dijelove izvora uvijek potrebno uzeti s mjerom opreza. Prema podacima koje ovdje bilježimo nekolicina najmlađih vojnika imala je osamnaest godina (primjerice Nikola Barišević, Antun Brunetić, Bartol Paliselli i Jure Vrvarić iz Zadra, Mijo Jurko i drugi), dočim su najstariji vojnici bili Andrija Galvanić s područja Cetinske krajine (38 godina) i pifarist Andreas Gligoropulo, zavičajem vjerojatno Grk (41 godina). Kada se svi ovi podaci o dobi vojnika uzmu u obzir (uz prethodno spomenute ograde), prosječna je dob bila 26 godina, što u cijelosti odgovara starosnoj strukturi prekomorskih pješaka. I ovdje su popisivači 
Bućine vojnike doživljavali kao osobe srednjega rasta, dočim je malen broj njih svrstan u kategorije krupan (Jakov Aliprandić, Lovro Benedetić, Filip Drašković iz Karlobaga i drugi), visok (Ličanin Šime Tomović, Nikola Veselinović iz Biljana i Marko Ostojić iz Biovičina Sela) i nizak (Ivan Borišević iz Zadra, Luka Drakulov iz plemena Cuce, Ivan Franov iz Kotora i Ivan Kloper iz Kranjske). Boja kose ovdje analiziranih vojnika najčešće je smeđa, a iznimka su crnokosi pripadnici postrojbe: Andrija Galvanić, Jovo Jovov iz Kotora, Nikola Veselinović i Lovro Kačić iz Zadra. Naposljetku, najstariji član postrojbe - Grk Gligoropulo opisan je kao sjedokos (griso).

Deset je satnija djelovalo u Bućinoj pukovniji tijekom idućih nekoliko godina (1738. - 1741.), ${ }^{54}$ a njihovi su zapovjednici gotovo istovjetni prethodnome popisu. ${ }^{55}$ Popis koji se odnosi na pukovnika Buću načinjen je 1. lipnja 1740. godine. Mjesto nastanka popisa nije razvidno iz spisa, ali najvjerojatnije je riječ o Mlecima. Satnija je u svojemu osnovnom sastavu brojila 47 časnika, dočasnika i običnih vojnika, a pretežit broj njih istovjetan je prethodno raščlanjenome popisu. Iz osnovnoga je sastava naknadno prekriženo osam vojnika, a na njihovo su mjesta prispjela četvorica novih pješaka od kojih su kroz neko vrijeme dvojica također zabilježena kao neprisutni u jedinici. Uzevši prethodno u obzir, možemo zaključiti da je, s obzirom na izrazitu podudarnost istih osoba kao i u popisu iz 1737. godine, i ovdje struktura zavičajnoga podrijetla nalik prethodnoj. Isto se, naravno, odnosi i na zabilježene tjelesne značajke svakoga pojedinog vojnika. ${ }^{56}$

\section{Zaključno razmatranje}

Prethodno načinjena raščlamba vojnoga djelovanja pukovnika Stjepana Buće u rasponu od 1715. do 1741. godine zorno nam predočava životni put jednoga tipičnog hrvatskog časnika u mletačkoj vojsci u 18. stoljeću. Višedesetljetno vođenje pukovnije i njoj pripadajućih satnija zasigurno je rezultat uspješno provedenoga vojnog poduzetništva kakvo su, uostalom, poduzimali i brojni drugi članovi njegove obitelji, ali i drugi časnici iz Dalmacije i Boke. Stjepanovo djelovanje zahvaća i razdoblje Drugoga morejskog rata kada - prema podacima iz

\footnotetext{
${ }^{54}$ RI-ASVe-0715-Inquisitori ... pubblici ruoli, Oltramarini, b. 508. i 509. Reggimento Bucchia Steffano e Antonio (1738. - 1741.).

${ }^{55}$ To su kapetan Ivan Valerijan Ambati (Krf, 1741., dva popisa; Mleci, 1741.), kapetan Anđelo Franco (Krf, 1741.; Mleci, 1741.), kapetan Juraj Gerano (Mleci, 1740.), kapetan Juraj Klarić (Krf, 1741.; Mleci, 1741.), kapetan Pavao Matutinović (Krf, 1741.; Mleci, 1741.), pukovnik Ivan Napadić (Krf, 1741. - potom ga nasljeđuje kapetan Jeronim Bachilli), potpukovnik Josip Preradović (?, 1739.; Mleci, 1741.), bojnik Petar Juraj Preradović (?, 1739.;Krf, 1741.; Mleci, 1741.), kapetan Nikola Račić (Mleci, 1739. i 1741.; Krf, 1741.), bojnik Juraj Sablić (Mleci, 1738. - 1741., ukupno 11 popisa) i kapetan Tripun Štukanović (Mleci, 1741.).

${ }^{56}$ Isto se odnosi i na satniju Stjepana Buće popisano u svežnju 509 navedenoga arhivskog fonda. Popisi su nastali u Mlecima 1. lipnja i 31. kolovoza 1741. i na ovome mjestu nisu - zbog prevelike podudarnosti osoba - uzeti u podrobnije razmatranje.
} 
izvora - njegova pukovnija broji velik broj satnija koje najčešće djeluju duž istočnojadranske obale. U kasnijemu, mirnodopskom razdoblju Bućine su satnije velikim dijelom koncentrirane duž mletačke terraferme, ali i na Levantu. Zavičajna struktura vojnoga ljudstva Bućine pukovnije ocrtana je kroz raščlambu njegove osobne satnije, a u njoj su prevladavali vojnici iz unutrašnjosti Crne Gore, Bokelji te vojnici iz dijela crnogorskoga priobalja koje se već odavno nalazilo u sastavu Osmanskoga Carstva (Bar, Spič, područja uz Skadarsko jezero i drugo). Primjetan je i udio Dalmatinaca, ali i - iako u pojedinačnim primjerima - i vojnika iz sjeverne Hrvatske, s područja Dubrovačke Republike, Hercegovine, Albanije i drugih nemletačkih dijelova istočnojadranske obale. Uzevši prethodno ocrtane značajke vojne karijere Stjepana Buće, može se na kraju istaknuti kako je riječ o uspješnom vojnom poduzetniku i časniku zavičajem $s$ hrvatskoga uzmorja tijekom više desetljeća 18. stoljeća. 


\section{PRILOZI}

PRILOG 1. Sastav osobne satnije pukovnika Stjepana Buće prema popisu načinjenome u Splitu 25. siječnja 1715. godine (RI-ASVe-0715-Inquisitori ... pubblici ruoli, Oltramarini, b. 501, Reggimento Bucchia Steffano e Antonio, 1715. - 1726.)

1. Pukovnik (Colonnello) Stjepan Buća

2. Potkapetan (Capitan tenente): Vicko Blavor

3. Narednik (Sargente): Krsto Nikov - Niko

4. Kaplar (Caporal): Pavo Josov - Joso

5. Bubnjar (Tamburo): Marko Milošev - Miloš - Vrba kraj Cetinja

6. Bubnjar (Tamburo): Marko Nikov - Niko - Njeguši

Vojnici (Soldati, Fanti):

7. Jeronim Antun - Antun

8. Petar Antun - Antun ${ }^{57}$

9. Stanko Arcegović - Grbalj58

10. Marko Božov - Božo

11. Vujadin Cvjetković - Cvjetko ${ }^{59}$

12. Vuko Čuković - Pješivci (Pliesiuzzi) u Katunskoj nahiji ${ }^{60}$

13. Jovo Drakulović - Drakule - Grbalj

14. Đuro Ivanov - Ivan - Orahovac (Boka kotorska) ${ }^{61}$

15. Komlen Ivanov - Ivan ${ }^{62}$

16. Milutin Ivanov - Ivan

17. Marko Josov - Joso

18. Jovan Jovanov - Jovan - Gradac kraj Podgorice ${ }^{63}$

19. Radule Jovov - Jovo - Bjeluši

20. Ivan Longov - Longo - Crna Gora

21. Rade Markov - Marko

22. Petar Mičević - Nikac - Gradac ${ }^{64}$

23. Staniša Milin - Mile - Cuce

${ }^{57}$ Naknadno prekrižen.

${ }^{58}$ Naknadno prekrižen.

${ }^{59}$ Preminuo 11. travnja 1716. godine te je naknadno prekrižen.

${ }^{60}$ Naknadno prekrižen.

${ }^{61}$ Naknadno prekrižen.

${ }^{62}$ Naknadno prekrižen.

${ }^{63}$ Naknadno prekrižen.

${ }^{64}$ Naknadno prekrižen. 
24. Periša Milutinov - Milutin - Grbalj ${ }^{65}$

25. Tomo Milutinov - Milutin - Orahovac ${ }^{66}$

26. Vuko Nikov - Niko - Njeguši ${ }^{67}$

27. Vučić Novaković - Novak - Pješivci

28. Filip Paliživović - Zaljuta (Gornja Zaljut kraj Cetinja) ${ }^{68}$

29. Ilija Pejanović - Pejan - Pješivci

30. Pero Peranov - Peran

31. Niko Perov - Pero

32. Rade Perov - Rade

33. Milutin Petrov - Petar - Banjani

34. Drago Popović - Pješivci ${ }^{69}$

35. Miko Radov - Rado - Grbalj ${ }^{70}$

36. Jovo Radov - Rade - Pobori

37. Nikola Radović - Rade - Bijelo polje $\mathrm{e}^{71}$

38. Ilija Raićev - Raić - Orahovac

39. Jovo Sredanov - Sredan - Zaljuta ${ }^{72}$

40. Komlen Sredanov - Sredan -Pješivci

41. Đurko Stefanov - Stefan - Bujari ${ }^{73}$

42. Andrija Stijepov - Stijepo - Pješivci

43. Milo Stijepov - Stijepo - Crmnica

44. Vuksan Tomin - Toma - Orahovac ${ }^{74}$

45. Milan Tomov - Toma - Brajići

46. Rade Vrbica - Vrbica - Njeguši

47. Marko Vučetin - Vučeta - Njeguši ${ }^{75}$

48. Marko Vučetin - Vučeta - Pobori ${ }^{76}$

${ }^{65}$ Naknadno prekrižen.

${ }^{66}$ Naknadno prekrižen.

${ }^{67}$ Naknadno prekrižen.

${ }^{68}$ Naknadno prekrižen.

69 Naknadno prekrižen.

70 Naknadno prekrižen.

${ }^{71}$ Naknadno prekrižen.

${ }^{72}$ Naknadno prekrižen.

${ }^{73}$ Naknadno prekrižen.

${ }^{74}$ Naknadno prekrižen.

75 Naknadno prekrižen.

${ }^{76}$ Naknadno prekrižen. 
49. Vukota Vučev - Vuko - Kličići ${ }^{77}$

50. Petar Vučinov - Vučina - Ubli kraj Podgorice

51. Miloš Vukadin - Vukadin - Pješivci

52. Petar Vukadinović - Vukadin - Kličići

53. Vukota Vukašinović - Vukašin - Pješivci (Plienuzzi)

54. Vuko Vukosavov - Vukosav - Njeguši ${ }^{78}$

55. Petar Vukotić - Vukota - Grbalj ${ }^{79}$

56. Ivo Vukov - Vuko - Grbalj

57. Stipan Vukov - Vuko - Pješivci

Naknadno dopisani:

1. Zastavnik (Alfier): Pavao - Zadrima

2. Kaplar (Caporal): Jovo Vučićev - Vučić - Herceg Novi

3. Mornar (Mariner): Tripun Muzača - Stjepan - Prčanj

Vojnici (Soldati):

4. Gega Antunović - Antun - Skadar

5. Antun Bernardi - Franjo

6. Krsto Božov - Božo

7. Mihajlo Bulavić - Radojica - Banjani

8. Mihajlo Dabović - Petar - Kruševice

9. Giacomo Dam... - Antonio

10. Battista Ferrari - Jakov

11. Božo Gujičin - Gujica - Trebinje

12. Đuro Ivanov - Orahovac

13. Tripo Jovanov - Jovan - Risan ${ }^{80}$

14. Todor Jovanović - Jovan - Grbalj ${ }^{81}$

15. Vujadin Jovanović - Jovan - Grbalj ${ }^{82}$

16. Đuro Jovov - Jovo

17. Ilija Markov - Marko

18. Krsto Markov - Marko

${ }^{77}$ Naknadno prekrižen.

${ }^{78}$ Naknadno prekrižen.

${ }^{79}$ Naknadno prekrižen.

${ }^{80}$ Naknadno prekrižen.

${ }^{81}$ Naknadno prekrižen.

${ }^{82}$ Naknadno prekrižen. 
19. Pavao Milovanov - Milan - Grbalj

20. Damjan Mitrov - Mitar - Trebinje

21. Vuksan Nikov - Niko - Njeguši

22. Luketa Pangulić - Ilija

23. Giuseppe Patinon

24. Ilija Perov - Pero - Kaštel Lastva (današnji Petrovac)

25. Grgo Petkov - Petko

26. Stijepo Petrov - Petar - Grahovo

27. Pero Radojev - Rade - Bogdašići

28. Đuro Radonjić - Radonja - Bjelopavlovići

29. Milin Radulović - Radule - Trebinje

30. Ivan Stanojev - Stanoje - Njeguši

31. Ivan Stjepanov - Stjepan - Trebinje

32. Pero Tomov - Tomo - Sveti Stefan

33. Marko Vukadinov - Vukadin

34. Petar Vukov - Vuko - Grbalj 
PRILOG 2. Sastav osobne satnije pukovnika Stjepana Buće prema popisu načinjenome u Bresciji 4. kolovoza 1727. godine (RI-ASVe-0715-Inquisitori ... pubblici ruoli, Oltramarini, b. 502, Reggimento Bucchia Steffano e Antonio, 1726. - 1728.)

1. Pukovnik (Colonnello) Stjepan Buća

2. Potkapetan (Capitan tenente): Franjo Kažotić (Casotti)

3. Zastavnik (Alfier): Pavao - Zadrima (područje uz Skadarsko jezeru u današnjoj Albaniji

4. Narednik (Sargente): Krsto Nikov - Niko

5. Narednik u pričuvi (Sargente riformato): Stojan Milić

6. Kaplar (Caporal): Matija Brsaljević - Krsto - Vrgorac - 32 - visok - smeđokos

7. Kaplar (Caporal): Ilija Raićev - Raić - 27 - srednjega rasta - smeđokos - brkovi

8. Bubnjar (Tamburo): Franjo Pišenić - Andrija - dječak - malenoga rasta

Vojnici (Soldati, Fanti):

9. Ivan Antonov - Anton - Istra - 39 - visok - smeđokos

10. Ivan Balšić - Josip - Kotor - 25 - nizak -smeđokos - svjetao

11. Grgur Devetak - Primož - Senj - 25 - srednjega rasta - smeđokos

12. Milutin Ivanov - Ivan - Cuce - 24 - nizak - smeđokos - taman

13. Petar Ivanov - Ivan - Ubli ${ }^{83}-27$ - srednjega rasta - smeđokos - taman

14. Ivan Jurković - Jure - Trogir - 35 - srednjega rasta - smeđokos

15. Juraj Kočevac - Luka - Trst - 39 - nizak - smeđokos

16. Nikola Kruta - Lazar - Albanija - 24 - nizak - smeđokos - svjetao

17. Ivan Longov - Longo - Crna Gora - 24 - srednjega rasta - smeđokos

18. Staniša Milin - Mile - Cuce - 28 - nizak - smeđokos - svjetao

19. Antun Nikolin - Nikola - Šibenik - 20 - srednjega rasta - crnokos

20. Marko Nikolin - Nikola - Crna Gora - 26 - srednjega rasta - smeđokos

21. Pero Nikolin - Nikola - Herceg Novi - 23 - krupan

22. Tripun Paskvalović - Franjo - Kotor - 23 - nizak - smeđokos - taman

23. Petar Pejanov - Pejan - Telagi (?) - 30 - srednjega rasta - smeđokos (kovrčav) - taman

24. Ivan Perov - Pero - Ubli - 63 - srednjega rasta

25. Milutin Petrov - Petar - Banjani - 32 - srednjega rasta - smeđokos - svjetao

${ }^{83}$ Naselje Ubli nalazi se na području općina Herceg Novi, Bar, Podgorica, Cetinje i Nikšić. 
26. Stijepo Radović - Rado - Paštrovići - 22 - krupan - smeđokos - taman

27. Ludovik Spadari - Spadari (?) - Zadar - 19 - srednjega rasta - smeđokos svjetao

28. Niko Stijepov - Stijepo - Kotor - 17 - nizak - smeđokos

29. Stojan Stijepović - Genam (?) - Crna Gora - 23 - srednjega rasta - smeđokos

30. Joko Stipanov - Stijepo - Paštrovići - 21 - krupan - smeđokos

31. Primas (Primož) Striozzi - Primas (Primož) - Poreč - 28 - nizak - smeđokos - svjetao

32. Matija Sušilj (Šušilj) - Grgo - 26 - srednjega rasta - smeđokos - svjetao

33. Luka Vujov - Vujo - Spič - 29 - srednjega rasta - smeđokos - taman

34. Rade Vrbica - Vrbica - Njeguši - 26 - srednjega rasta - smeđokos - taman

35. Vuko Vukadinov - Vukan - Ostrinić (?) - 28 - srednjega rasta - smeđokos

36. Petar Vukadinović - Vukadin - Kličići - 32 - srednjega rasta - smeđokos veliki brkovi

37. Stipan Vukov - Vuko - Grbalj - 40 - visok - smeđokos - svjetao

38. Stipan Vukov - Vuko - Pješivci - nizak - smeđokos - taman 
PRILOG 3. Sastav osobne satnije pukovnika Stjepana Buće prema popisu načinjenome u Bergamu 18. travnja 1731. godine (RI-ASVe-0715-Inquisitori ... pubblici ruoli, Oltramarini, b. 504, Reggimento Bucchia Steffano e Antonio, 1731. - 1733.)

1. Pukovnik (Colonnello) Stjepan Buća

2. Kapetan u pričuvi (Capitan riformato): Franjo Fanfonja

3. Potkapetan (Capitan tenente): Maksim Obrić

4. Zastavnik (Alfier): Tripun Buća

5. Narednik (Sargente): Matija Brsaljević - Krsto

6. Narednik u pričuvi (Sargente riformato): Pietro Dupre

7. Narednik u pričuvi (Sargente riformato): Stojan Milić

8. Kaplar (Caporal): Petar Pejanov - Pejan - Telagi (?)

9. Kaplar (Caporal): Ilija Raićev - Raić

10. Bubnjar (Tamburo): Franjo Pišenić - Andrija

11. Pifarist (Piffaro): Scipion Ferrante

12. Pifarist (Piffaro): Karlo Paleit - Kotor

Vojnici (Soldati, Fanti):

13. Ivan Antonov - Anton - Istra

14. Ivan Balšić - Josip - Kotor

15. Bartul Bartulić - Jakov - Kotor - srednjega rasta - smeđokos

16. Marko Boškov - Boško - Trebinje - 21 - srednjega rasta - crnokos

17. Niko Božov - Božo - Luštica - 24 - srednjega rasta - smeđokos

18. Grgur Devetak - Primož - Senj

19. Vicko Đurmetić - Tripo - Kotor

20. Antun Faciani - Krstitelj - Zadar - 25 - srednjega rasta - smeđokos

21. Jakov Franov - Frane - Kotor - 19 - nizak - smeđokos

22. Gion Gioni - Gion - Skadar - 26 - srednjega rasta - smeđokos

23. Prenz Giura - Giure - Livari - 20 - visok - smeđokos

24. Milutin Ivanov - Ivan - Cuce

25. Petar Ivanov - Ivan - Ubli

26. Đuro Ivić - Ivo - Grbalj - 27 - nizak - crnokos

27. Ivo Jakovljev - Jakov - Kotor - 21 - visok - crnokos

28. Ivan Jurković - Jure - Trogir

29. Juraj Kočevac - Luka - Trst

30. Jovo Kovačević - Niko - Grbalj - 21 - srednjega rasta - smeđokos 
31. Nikola Kruta - Lazar - Albanija

32. Ivan Longov - Longo - Crna Gora

33. Niko Ljubanović - Marko - Grbalj - 23 - visok - smeđokos

34. Staniša Milin - Mile - Cuci

35. Toma Mirković

36. Marko Nikolin - Nikola - Crna Gora

37. Pero Nikolin - Nikola - Herceg Novi

38. Petar Nikolin - Nikola - Pločice (Konavli) - 20 - srednjega rasta - smeđokos

39. Tripun Paskvalović - Franjo - Kotor

40. Rade Pejanov - Ivan - Zeta - 23 - srednjega rasta - smeđokos

41. Ivan Perov - Pero - Ubli

42. Milutin Petrov - Petar - Banjani

43. Marko Antun Pezzi - Antun - Kotor - 19 - srednjega rasta - smeđokos taman

44. Josip Picinelli - Martin - Kotor - 23 - visok - smeđokos

45. Stijepo Radov - Rade - Luštica - 19 - srednjega rasta - smeđokos

46. Marko Rašković - Raško - Luštica - 20 - srednjega rasta - smeđokos

47. Antun Romić - Franjo - Kopar - 30 - nizak

48. Ludovik Spadari - Spadari (?) - Zadar

49. Ivan Stanišić - Staniša - Kostanjica - 25 - srednjega rasta - smeđokos

50. Ilija Stijepov - Stijepo - Kotor - 20 - srednjega rasta - smeđokos

51. Niko Stijepov - Stijepo - Kotor

52. Jako Stiletović - Vuko - Lješević - 22 - srednjega rasta - smeđokos

53. Matija Sušilj (Šušilj) - Grgo

54. Marko Tenković - Pero - Grbalj - 22 - srednjega rasta - smeđokos

55. Luka Vujov - Vujo - Spič

56. Rade Vrbica - Vrbica - Njeguši

57. Petar Vukadinović - Vukadin - Kličići

58. Stijepo Vukov - Vuko - Luštica - 24 - srednjega rasta - smeđokos

59. Stipan Vukov - Vuko - Grbalj

60. Joko Zambelli - Joko - Luštica - 20 - srednjega rasta - smeđokos 
PRILOG 4. Sastav osobne satnije pukovnika Stjepana Buće prema popisu načinjenome u Mlecima (Lido) 24. travnja 1737. godine (RI-ASVe-0715-Inquisitori ... pubblici ruoli, Oltramarini, b. 507, Reggimento Bucchia Steffano e Antonio, 1737. - 1738.)

1. Pukovnik (Colonnello) Stjepan Buća

2. Potkapetan (Capitan tenente): Tripun Štukanović

3. Zastavnik (Alfier): Matija Brsaljević - Krsto

4. Narednik (Sargente): Petar Ivanov - Ivan - Ubli ${ }^{84}$

5. Kaplar (Caporal): Staniša Milin - Mile - Cuci ${ }^{85}$

6. Kaplar (Caporal): Marko Nikolin - Nikola - Crna Gora ${ }^{86}$

7. Kaplar (Caporal): Jovo Radov - Rade - Njeguši - srednjega rasta - smeđo$\mathrm{kos}^{87}$

8. Bubnjar (Tamburo): Pavao Mano

9. Pifarist (Piffaro): Karlo Paleit - Kotor ${ }^{88}$

Vojnici (Soldati, Fanti):

10. Jakov Aliprandić - Jakov - 24 - krupan - smeđokos ${ }^{89}$

11. Ivan Balšić - Josip - Kotor

12. Nikola Barišević - Mate - 18 - srednjega rasta - smeđokos

13. Lovro Benedetić - Jakov - 24 - krupan - smeđokos

14. Ivan Borišević - Matija - Zadar - 18 - nizak - smeđokos ${ }^{90}$

15. Jakov Borišević ${ }^{11}$

16. Marko Boškov - Boško - Trebinje

17. Mileta Boškov - Boško - Kotor - 22 - srednjega rasta - smeđokos

18. Antun Brunetić - Petar - Zadar - 18 - srednjega rasta - smeđokos

19. Grgur Brusić - Antun - Karlobag - 24 - srednjega rasta - smeđokos

20. Janko Dabo - Dabo - Crna Gora - 28 - srednjega rasta - smeđokos $^{92}$

21. Grgur Devetak - Primož - Senj

22. Luka Drakulov - Drakule - Cuce - 19 - nizak - smeđokos

${ }^{84}$ Kroz proteklo je vrijeme od običnoga vojnika napredovao u čin narednika. Naknadno je prekrižen.

${ }^{85}$ Kroz proteklo je vrijeme od običnoga vojnika napredovao u čin kaplara.

${ }^{86}$ Kroz proteklo je vrijeme od običnoga vojnika napredovao u čin kaplara.

${ }^{87}$ Naknadno prekrižen.

${ }^{88}$ Naknadno prekrižen.

${ }^{89}$ Naknadno prekrižen.

${ }^{90}$ Naknadno prekrižen.

91 Naknadno prekrižen.

${ }_{92}$ Naknadno prekrižen. 
23. Filip Drašković - Mate - Karlobag - 25 - krupan - smeđokos

24. Frane Fabrović - Jure - Zadar - 20 - srednjega rasta - smeđokos ${ }^{93}$

25. Ivan Franov - Frane - Kotor - 20 - nizak - smeđokos

26. Andrija Galvanić - Lujo - Cetina - 38 - srednjega rasta - crnokos

27. Prenz Giura - Giure - Livari

28. Nikola Ilijin - Ilija - Kotor - 24 - srednjega rasta - smeđokos

29. Andrija Ivanov - Ivan - Herceg Novi - 34 - srednjega rasta - smeđokos

30. Frane Jovov - Jovo - Kotor - 25 - krupan - smeđokos

31. Jovo Jovov - Jovo - Kotor - 30 - visok - crnokos $^{94}$

32. Mijo Jurko - Matija - Dalmacija - 18 - srednjega rasta - crnokos $^{95}$

33. Ivan Kloper - Melkior - Kranjska - 30 - nizak - smeđokos ${ }^{96}$

34. Niko Kruta - Lazar - Herceg Novi ${ }^{97}$

35. Janko Lučić - Juro - 20 - srednjega rasta - smeđokos

36. Petar Lukin - Luka - 24 - krupan - smeđokos

37. Antun Markov - Marko - Istra - 20 - srednjega rasta - smeđokos

38. Frane Markov - Marko ${ }^{98}$

38. Mate Mudraša - Marko - Zadar - 27 - srednjega rasta - smeđokos

40. Aćim Nikov - Niko - Herceg Novi - 24 - srednjega rasta - smeđokos

41. Bartol Paliselli/Piliselli - Krstitelj - Zadar - 18 - nizak - smeđokos

42. Marko Perić - Petar - Biograd - 25 - srednjega rasta - smeđokos ${ }^{99}$

43. Božo Rašica - Jovo - 20 - srednjega rasta - smeđokos

44. Ludovik Spadari - Zadar

45. Ivan Stanišić - Staniša - Kostanjica

46. Dominik Šantić - Ivan - Zadar - 18 - srednjega rasta - smeđokos

47. Lovro Šitelić - Matej - Istra - 20 - srednjega rasta - smeđokos ${ }^{100}$

48. Ivan Tomov - Toma - Dubrovnik - 30 - srednjega rasta - smeđokos

49. Šime Tomović - Petar - Lika - 20 - visok - smeđokos

50. Anđelo Trešović/Trusović - Ivan - Istra - 21 - srednjega rasta - smeđokos

93 Naknadno prekrižen.

94 Naknadno prekrižen.

${ }^{95}$ Naknadno prekrižen.

${ }_{96}$ Naknadno prekrižen.

${ }_{97}$ U prethodnom popisu kao njegov zavičaj navedena je Albanija.

98 Naknadno prekrižen.

99 Naknadno prekrižen.

${ }^{100}$ Naknadno prekrižen. 
51. Frederik Vagner - Juraj - Beč - 26 - srednjega rasta - smeđokos

52. Krstitelj Venier - Jakov - Zadar - 30 - srednjega rasta - smeđokos

53. Jure Vrvarić - Jure - Zadar - 18 - nizak - smeđokos

54. Nikola Veselinović - Petar - Biljane - 30 - visok - crnokos

55. Luka Vujov - Vujo - Spič

56. Stipan Vukov - Vuko - Grbalj ${ }^{101}$

57. Krsto Zubavić - Stipan - 25 - krupan - smeđokos ${ }^{102}$

Naknadno dopisani:

1. Zastavnik (Alfier): Juraj Karađija

2. Narednik (Sargente): Franjo Lučić - Nikola - Senj

3. Mornar (Mariner): Janni Anifondi ${ }^{103}$

4. Mornar (Mariner): Stavervachi Scordili ${ }^{104}$

5. Pifarist (Piffaro): Andreas Gligoropulo - Grčka - 41 - srednjega rasta - sjedokos

Vojnici (Soldati):

6. Niko Andrijin - Andrija - Grbalj - 24 - srednjega rasta - smeđokos ${ }^{105}$

7. Pave Antunov - Antun - Kotor ${ }^{106}$

8. Frane Barić - Ivan - Istra

9. Antonio Carisolli - Battista - Cologno Monzese - srednjega rasta - smeđo$\operatorname{kos}^{107}$

10. Ante Dobrović - Mate - Hvar ${ }^{108}$

11. Stojan Giljatović - Despot - Raštević - 22 - srednjega rasta - smeđokos

12. Nikola Ivanović - Zadar - 21 - srednjega rasta - smeđokos

13. Lovro Kačić - Stjepan - Zadar - 18 - srednjega rasta - crnokos

14. Antun Markov ${ }^{109}$

15. Ivan Miletić - Petar - Split - 20 - srednjega rasta - smeđokos

\footnotetext{
${ }^{101}$ Naknadno prekrižen.

${ }^{102}$ Naknadno prekrižen.

${ }^{103}$ Naknadno prekrižen.

${ }^{104}$ Naknadno prekrižen.

${ }^{105}$ Naknadno prekrižen.

${ }^{106}$ Naknadno prekrižen.

${ }^{107}$ Naknadno prekrižen.

${ }^{108}$ Naknadno prekrižen.

${ }^{109}$ Naknadno prekrižen.
} 
16. Marko Ostojić - Ilija - Biovičino Selo - 23 - visok - smeđokos ${ }^{110}$

17. Marin Pezzi - Antun - Kotor - 27 - srednjega rasta - smeđokos

18. Giacomo Spadon - Luca - Palmanova - 32 - nizak - smeđokos ${ }^{111}$

19. Mate Šerić - Jure - 28 - nizak - smeđokos 


\section{Arhivi}

Hrvatska - Državni arhiv u Zadru, Zadar - fond 1 - Generalni providuri za Dalmaciju i Albaniju (HR-DAZD-1-GPDA)

Repubblica Italiana - Archivio di Stato di Venezia - fondo 0715 - Inquisitori sopra l'amministrazione dei pubblici ruoli (RI-ASVe-0715-Inquisitori ... pubblici ruoli)

\section{Literatura}

Čoralić, Lovorka. "Život i djelovanje kotorskih patricija u Mlecima od 16. do 18. stoljeća". Radovi Zavoda za hrvatsku povijest Filozofskog fakulteta Sveučilišta u Zagrebu 31 (1998): 131-140.

Čoralić, Lovorka. "Zadarski patricij Lujo Detriko (1672. - 1749.) - zapovjednik hrvatske konjice (Cavalleria Croati)". Zbornik Odsjeka za povijesne znanosti Zavoda za povijesne i društvene znanosti HAZU 32 (2014): 99-129.

Čoralić, Lovorka. "Albanski vojnici u mletačkim prekojadranskim kopnenim postrojbama (18. stoljeće)”. Povijesni prilozi 37 (2018), br. 54: 183-214.

Čoralić, Lovorka; Katušić, Maja. "Kotorski plemići Frano Buća, Gabrijel Vraćen i Nikola Paskvali - časnici mletačkih prekojadranskih vojnih postrojbi (prva polovica XVIII. st.)". Povijesni prilozi 31 (2012), br. 42: 249-273.

Čoralić, Lovorka; Katušić, Maja. "Peraštanin Tripun Štukanović - pukovnik mletačkih oltramarina (druga polovica 18. st.)". Anali Zavoda za povijesne znanosti HAZU u Dubrovniku 50 (2012): 385-410.

Čoralić, Lovorka; Katalinić, Vjera; Katušić, Maja. "Bubnjari, timpanisti, trubači i pifaristi: glazbena pratnja u mletačkim prekojadranskim kopnenim postrojbama u 18. stoljeću". Arti musices 47 (2016), br. 1-2: 27-78.

Čoralić, Lovorka; Markulin, Nikola. "Kotorski plemić Benedikt Paskvali (1704. 1790.) - zapovjednik mletačkih prekomorskih pješačkih postrojbi”. Acta Histriae 26 (2018), br. 2: 393-428.

Čoralić, Lovorka; Markulin, Nikola. "Vojni inženjer Antun Marković (u. 1767.) i njegova pješačka pukovnija". Radovi Zavoda za povijesne znanosti HAZU u Zadru 60 (2018): 167-204.

Katušić, Maja. "Društvena i demografska struktura Kotora u 18. stoljeću”. Doktorska disertacija, Sveučilište u Zagrebu, 2013.

Krasić, Stjepan; Radauš, Tatjana. "Buća, plemićka obitelj u Kotoru". U: Hrvatski biografski leksikon sv. 2, 410-412. Zagreb: Jugoslavenski leksikografski zavod "Miroslav Krleža”, 1989. 
Markulin, Nikola. "Vojno poduzetništvo u Mletačkoj Dalmaciji i Boki za vrijeme Morejskog rata (1684. - 1699.)". Radovi Zavoda za povijesne znanosti HAZU u Zadru 56 (2014): 91-142.

Markulin, Nikola. "Mletačka vojna organizacija u Dalmaciji i Boki od Morejskog rata (1684. - 1699.) do Požarevačkog mira 1718.”. Doktorska disertacija, Sveučilište u Zadru, 2015.

Markulin, Nikola. "Vojno poduzetništvo u Mletačkoj Dalmaciji i Boki od 1700. do 1718. godine”. Povijesni prilozi 35 (2016), br. 51: 159-196.

O' Connell, Monique. Men of Empire: Power and Negotiation in Venice's Maritime State. Baltimore: The Johns Hopkins University Press, 2009.

Reinhard, Wolfgang (ur.). Power Elites and State Building. New York: Oxford University Press, 2005. 
Lovorka Čoralić

Nikola Markulin**

\section{Stjepan Buća, Kotor's Nobleman and Commander of the Venetian Overseas Infantry, and the Composition of His Regiment (First Half of the $18^{\text {th }}$ Century)}

One of the key preconditions for building up and maintaining the Venetian naval empire in the early modern period was a successful connection between the interests of the local elites and the central authorities. The Venetian possessions in the Eastern Adriatic were no exception to this rule, and the noble families from the communes of Dalmatia and Bokelj played a particularly important role in this respect. For generations, their members held various public posts of local significance throughout the said area. From the mid- $17^{\text {th }}$ century, the local elites were increasingly involved in the Venetian military service. In this way, the Venetian military organization in the Eastern Adriatic region became the most important field in which the interests of the central authorities in Venice and the local elites were intertwined and firmly connected. An excellent example for studying this form of integration between the local elites and the state is the noble family of Buća (Bucchia), one of the ancient and especially respectable noble kindreds of Kotor. After some members of the family distinguished themselves in important civil services of the Republic, the Buća became more intensely involved in the Venetian military organization during the last decades of the $17^{\text {th }}$ century. Stjepan Buća, his brother Franjo, and their father Jeronim made an excellent military career. Studying the military path of these officers, and this paper focuses on Stjepan's in particular, clearly outlines the pattern of integration of the Eastern Adriatic local elites into the Venetian maritime empire. The main part of the study is an analysis of the infantry regiment Oltramarina, commanded by Colonel Stjepan Buća, in the period from 1715 to 1741. The authors bring transcripts of various documents that are directly related to the military activity of Stjepan Buća as a colonel in Venetian infantry units.

Keywords: Kotor, Boka Kotorska, Stjepan Buća, Venetian Republic, Venetian military organization, early modern period

" Lovorka Čoralić, Croatian Institute of History, Opatička 10, 10000 Zagreb, Croatia, E-mail: lovorka@ isp.hr

*** Nikola Markulin, Nikole Tesle 14D, 23000 Zadar, Croatia, E-mail: nikola.markulin@gmail.com 